\title{
Türkiye'deki Bütünleşik Kıyı Alanları Yönetimi Süreçlerinin Stratejik Mekansal Planlama Süreçleri ile İlişkili Olarak Değerlendirilmesi
}

\author{
An Evaluation of Integrated Coastal Zone Management Processes \\ in Relation to Strategic Spatial Planning Processes in Turkey
}

\author{
(D) Murat Gülbitti, ${ }^{1}$ (1) Burcu Halide Özüduru² \\ ${ }^{1}$ Yüksek Şehir Plancısı, Ankara \\ ${ }^{2}$ Gazi Üniversitesi Mimarlık Fakültesi, Şehir ve Bölge Planlama Bölümü, Ankara
}

\section{ÖZ}

Bu makale stratejik mekansal planlama sürecleri ile ilişkili olarak Türkiye'deki Bütünleşik Kıyı Alanları Yönetimi (BKAY) süreçlerini incelemekte ve bu süreçlerin özelliklerini stratejik planlama pratikleri ile birlikte açıklamayı hedeflemektedir. Dünyada ve Türkiye'de özellikle 1990'lardan sonra stratejik mekansal planlamanın kapsamlı planlamaya alternatif olarak kentsel ve bölgesel planlama uygulamalarında etkili olmasıyla ortaya çıkmıştır. Bu planlama yaklaşımı kapsamlı planlama ile karşılaştırıldığında daha esnek, eylem odaklı, katılımı destekleyerek ve karar alma süreçlerinde müzakereci olma özellikleriyle farklı seviyelerdeki devlet kurumlarının farklı ölçeklerde birlikte çalışmasını (çok düzeyli yönetişim) ve farklı sektörlerin işbirliğini ön plana çıkarmaktadır. Ancak, 2000'li yıllarda stratejik planların uygulama süreçlerine entegre edilememesi, yetki karmaşasından doğan sorunlar, plan süreçlerini destekleyen eylem plan ve programlarının eksikliği ile izleme ve değerlendirme aşamalarındaki yetersizlikler, bu planların öneminin azalmasına neden olmuştur. Son yıllarda, stratejik mekansal planlama yaklaşımının kentsel ve bölgesel planlama süreçleri ile ilişkilendirilmeye çalışıldığı görülse de bu konuda yapılan çalışmaların yetersiz olduğu anlaşılmaktadır. Bu makalede, bir stratejik mekansal planlama süreci olarak BKAY ve Planlama sürecinin mevcut yasal, kurumsal yapı ve planlama süreçleri ile ilişkisi incelenecektir. BKAY süreçlerinde yer almış uzmanlarla yapılan derinlemesine görüşmeler ışığında bu süreçlerin olumlu ve olumsuz yönleri belirlenerek, BKAY sürecinin yeniden etkinleştirilmesi için yapılması gereken düzenlemeler tartışılacaktır. Bu görüşmelerden elde edilen çıkarımlar ile kıyı alanları ve planlaması ile mevcut düzenlemelerin iyileştirilmesi için öneri planlama politikaları ve programları geliştirilebilecek; stratejik mekansal planlamanın güçlü yönleri ile kıyı alanlarının sürdürülebilir şekilde yönetimi arasında ilişki kurulabilecektir.

Anahtar sözcükler: Bütünleşik kıyı alanları yönetimi ve planlaması; kıyı; kıyı alanları; stratejik mekansal planlama.

\section{ABSTRACT}

The purpose of this article is to evaluate Integrated Coastal Zone Management (ICZM) features and processes in relation to strategic spatial planning processes and practices in Turkey. Strategic planning processes have become effective in urban and regional planning and evolved as an alternative to comprehensive planning processes, in particular, in the 1990s. These processes are more flexible, action-oriented, participatory and deliberative, and they support planning activities that focus on collaboration of different levels of state institutions on various scales (multi-level governance) and sectors compared to comprehensive planning. In the 2000s, however, failure to integrate strategic plans into implementation processes, problems arising from the authority incompatibility, lack of action plans and programs that support planning processes and the inaptitude in monitoring and evaluation stages have reduced the significance of these plans. In recent years, while strategic spatial planning approaches are still associated with urban and regional planning processes, it is observed that the studies on this subject are insufficient. In this article, existing legal, institutional and planning structure of ICZM and Planning processes as significant strategic spatial planning processes will be analysed. The positive and negative aspects of ICZM processes and the possible re-enabling of ICZM processes will be discussed under the light of in-depth interviews with experts that are involved in ICZM processes in various cities in Turkey. The findings of the content analysis with these experts will offer an opportunity to develop new planning policies and programs for the improvement of current regulations regarding coastal area and planning, and to establish a relationship between the strengths of strategic spatial planning and sustainable management of coastal areas along with planning practices.

Keywords: Integrated coastal zone management and planning; coast; coastal zones; strategic spatial planning.

Geliş tarihi: 15.03.2019 Kabul tarihi: 24.09.2019

Online yayımlanma tarihi: I2.02.2020

İletişim: Burcu Halide Özüduru.

e-posta: bozuduru@gmail.com 


\section{Giriş}

1970’lerde diğer disiplinlerde önem kazanmış stratejik planlama, Dünyada 1990'larda mekansal karşılığını bularak şehir planlama süreçlerinde etkili olmaya başlamıştır. Stratejik mekansal planlamaya duyulan ihtiyacın temelinde geleneksel planlamanın çok sektörlü ve çok aktörlü olması nedeniyle farklı ölçeklerdeki güncel problemlere çözüm getirememesi yatmaktadır (Albrechts, 200I; Healey, 1999). Kentlerde endüstrileşme sonrasındaki yeniden yapılanma, uydukentleşme, kırsal alanlarda yaşanan ekonomik problemler, araba kullanımının yaygınlaşması ile ortaya çıkan kentsel sorunlar yaşam alanlarının etkili şekilde planlanmasını gerektirmiştir. Çözüm olarak, alansal sorunlara alansal öneriler getirilmesi, ilgili alanlardaki işlevlerin analiz edilmesi önerilmiş; daha sonra bu durum da parçalı mekanlar oluşmasına ve yeni sosyo-mekansal gerçekliklerin keşfedilmesine neden olmuştur (Albrechts, 200I). Doğanın ve doğal kaynakların, örneğin dere yatakları ve vadiler ile ilişkili tüm açık alanların, sadece ekolojik kapsamda değil de kurallı bir mekansal sistem olarak ele alınması da bu keşfin bir sonucudur. Diğer doğal alanlar gibi kıyı alanları da parçalı mekansal sistemin önemli bir ögesi olarak planlama süreçlerinde yer almaya başlamıştır.

1996 yılında gerçekleşen Habitat II ile birlikte Türkiye'de yönetişim kavramının gündeme geldiği görülmektedir. Bu kavramın etkisi ile stratejik mekansal planlama kapsamında yapılan vurgu yetkilerin dağılımı, planlama uygulamaları ve yasal düzenlemeler arasındaki ilişkinin daha etkili bir şekilde sonuç vermesi için bir vizyon çerçevesinde planlama yapılması gerekliliği olmuştur ve bu yıllarda yapılan planların stratejik olarak uygulamayı yönlendirici olması ideal şartlarda olmasa da sağlanmıştır (Gedikli, 2004). Türkiye'de stratejik mekansal planlama prensipleri ilk kez 1996-2000 yıllarını kapsayan 7. Beş Yıllık Kalkınma Planı'nda yer almış, sonraki Kalkınma Planları'nda da kapsamı genişletilerek vurgulanmıştır. Bu planlarla birlikte bölge ölçeğinde kurumsal kapasitenin de geliştirilmesi gerekliliği ortaya çıkmış ve Bölgesel Kalkınma Ajansları kurulmuştur (Şimşek Deniz, 20।4). Kalkınma planlarının stratejik mekansal planlar ile birlikte ele alınmaya başlaması bölge planlama disiplininde de stratejik mekansal planlara ayrı bir önem kazandırmıştır.

Kıyı alanları ticari, turistik, endüstriyel, ulaşım ve iletişim kanalları gibi çok sayıda faaliyet ve kullanımların yer seçtiği belirgin bölge parçaları olarak hem doğal kaynakların, hem de insan etkinliklerinin yoğunlaştığı alanlardır. Bu nedenle de bu alanlarda yüksek nüfus, yoğun kentleşme ve yapılaşmanın olduğu görülmektedir. Ayrıca, kıyılarda kontrolsüz ve arıtılmadan salıverilen gaz ve katı atıklar, doğal alanların yapılaşmaya açılması, kıyıların doldurulması yoluyla arazi kazanımı, aşırı avlanma gibi nedenlere bağı olarak ekolojik dengelerin bozulması gibi çevre sorunlarının da en çok yaşandığı görülmektedir (Özelçi Eceral ve
Özdemir Sönmez, 20II). Bu nedenlerle, kıyı alanlarının planlanmasında stratejik mekansal planların öngördüğü gibi bir vizyon çerçevesinde çok düzeyli ve çok sektörlü planlama esasları geliştirilmesi gerekmektedir.

Bugüne kadar, doğal çevrenin önemli bir parçası olan kıyı alanlarının korunması ve aynı zamanda bu alanlardan ekonomik olarak yararlanılabilmesi sağlanılmaya çalışılmış; zamanla sürdürülebilir bir biçimde yönetilmesi ve planlanması için kıyı alanlarını bir bütün olarak ele alabilecek yeni yaklaşımlara gereksinim duyulmuştur. 1970'li yıllarla beraber kıyı alanları dünyada ayrı bir bölge olarak değer kazanmaya başlamıştır. 1992 yılında Rio kentinde gerçekleştirilen Çevre ve Kalkınma Konferansı sonucunda ise bütünleşik kıyı alanları yönetim (BKAY) süreci öne çıkarak önem kazanmıştır. Bu tarihten sonra dünyanın farklı bölgelerinde BKAY ile ilgili kuramsal ve uygulamaya yönelik girişimlerin sayısı artmış, bu konuda önemli seviyede bir deneyim ve bilgi birikimi oluşmuştur.

Avrupa Komisyonu BKAY'ı genel amacı sürdürülebilir kalkınma, kıyı alanlarının korunması ve biyolojik çeşitliliğin yaşatılması olan pratik uygulamayı sağlayabilecek sürekli bir idare işlemi olarak tanımlamaktadır (Bahar, 2007). Dünya Bankası tanımlamalarına göre ise BKAY, kıyı alanlarından sağlanan faydayı en yükseğe çıkarmayı ve bunu yaparken kıyıda konumlanan faaliyetlerin birbirleri, doğal kaynaklar ve çevre üzerindeki olumsuz etkilerini en aza indirmeyi hedefleyen bir planlama ve yönetim yaklaşımıdır (Sönmez ve Balaban, 2009). BKAY ile ilgili tanımlamalar incelendiğinde; kıyının yalnızca ekolojik özelliklerinin değil, ekonomik, sosyal ve kültürel boyutlarının da göz önünde bulundurulduğu görülmektedir. Bu tanımlamalarda, siyasal, yasal ve kurumsal gereksinimlere vurgu yapılarak doğal kaynakların korunması, sürdürülebilir kalkınmanın sağlanması, yönetsel yapının güçlendirilmesi, planlamanın gerçekleştirilmesi, denetim sistemlerinin kurgulanması ve halk katılımının sağlanması gibi konular üzerinde yoğunlaşan bir kaynak yönetim süreci üzerinde durulmaktadır.

Akdeniz Havzası ülkeleri başta olmak üzere uluslararası ölçekte BKAY konusu zamanla daha öncelikli olarak ele alınmaya başlanmıştır. Bu gelişmenin Türkiye'de de yansımaları görülmüş, kıyı alanlarında artan kentleşme ve turizm etkinlikleri ile birlikte özellikle 1980 'li yıllardan sonra; kıyı alanları yönetimi ve planlamasını doğrudan etkileyen imar, kıyı ve turizm ile ilgili yasal düzenlemelerin yürürlüğe konulması ile mekansal planlamada yerel yönetimler yetkilendirilmiştir. 1990’lı yılların sonuna kadar farklı kıyı bölgelerinde yerel yönetimler ile gerçekleştirilen plan, proje ve programlar Türkiye'nin ilk BKAY girişimleri olmuştur. Bu dönemde merkezi yönetim düzenleyici ve denetleyici tek yetkili kurum olmuştur. 2000'li yıllardan sonra ise BKAY ve planlaması, ulusal ölçekte ele alınan bir konu durumuna gelmiş ve 2007 yılından itibaren de doğrudan merkezi yönetim tarafından yürütülmeye başlanmıştır. 
Çevre ve Şehircilik Bakanlığı (ÇŞB)'nın 2014 yılında yayımlanan 'Mekansal Planlar Yapım Yönetmeliği'ne göre 'Bütünleşik Kıуı Alanları Planları (BKAP) mekansal planlama kademelenmesinde yer almayan kıyı ve etkileşim alanına özgü stratejik yaklaşımla hazırlanan ve imar planlarını yönlendiren plan olarak' tanımlanmaktadır. Bu tanım BKAY ve planlamasının bir stratejik mekansal planlama yaklaşımı olarak görüldüğünü göstermektedir. Bu kapsamda, bu makalenin amacı Türkiye'nin BKAY ve planlaması konusunda mevcut durumunun özelliklerinin incelenmesi, BKAY ve planlaması çalışmalarının daha etkin ve uygulanabilir olması için yönetsel, siyasal, kurumsal, yasal konularda yönlendirici plan, politika, program ve strateji önerilerinin geliştirilmesi ve Türkiye'ye özgü yaşanan problemlere yönelik çözümlerin üretildiği bir kentsel politika ve strateji paketinin hazırlanması yönünde olması gereken temel ilkelerin stratejik mekansal planlama süreçlerinin özellikleriyle ilişki kurularak ortaya konulmasıdır.

İlk olarak kapsamlı bir literatür taraması ile mevcut BKAY ve planlama süreci incelenmiş, ilgili yasal, kurumsal düzenlemeler ile planlama süreci üzerinden bir değerlendirme yapılmış ve Türkiye'ye özgü özellikler belirlenmiştir. Daha sonra, sürecin çeşitli aşamalarını daha iyi değerlendirip, önerilerde bulunmak amacıyla BKAY ile ilişkili süreçlerin farklı aşamalarında yer almış 24 uzmanla derinlemesine görüşmeler yapılmıştır. Görüşme konuları stratejik planlama süreçleri ile de ilgili olarak siyasal, kurumsal, yasal, planlama, izleme değerlendirme, bilgi farkındalık eğitim ve araştırma ve katılım boyutları olarak 7 başlıkta gruplandırılmıştır. Her başlık mevcut durum değerlendirmesi ve öneriler olarak iki ayrı grupta incelenmiştir.

Bu çalışma, Türkiye'deki kıyı politikaları, kıyı alanları yönetimi ile BKAY ve planlamasını geçmişten günümüze kapsamlı bir biçimde ele alan ve bu konudaki farklı uzmanları bir araya getirerek ileriye dönük çözüm önerilerini toplayan güncel ve özgün bir araştırma olması açısından önem taşımaktadır. Bu konuda yapılan araştırmalar genellikle, BKAY'ın bir boyutu ile ilgili olarak ya da belirli bir coğrafi alandaki çalışmaları kapsamaktadır. Bu araştırmada ise, BKAY Türkiye'de ortaya çıkan kuramsal ve uygulamaya yönelik yapısı ile ele alınmaktadır.

Bu makalede, giriş bölümünü takip eden, 2. bölümde Dünyada ve Türkiye'deki stratejik mekansal planlama çalışmalarının genel özelliklerinin BKAY ve planlama süreçleri ile ilişkisi kurulmaktadır. Daha sonra, 3. bölümde Türkiye'deki kıyı alanlarının durumu ve başlıca sorunları üzerinde durulmakta; 4. bölümde kıyı politikaları ve kıyı alanları yönetimi özellikleri açıklanmaktadır. 5. bölümde bu çalışma kapsamında yapılan derinlemesine görüşmelerden elde edilen bulgular sunulmaktadır. Değerlendirme ve sonuç bölümü olan 6 . bölümde ise stratejik mekansal planlama çerçevesinde BKAY sürecinin değerlendir- mesi yapılarak, öneri düzenlemelerin ortak özellikleri ortaya konulmaktadır.

\section{Stratejik Mekansal Planlama Çalışmaları ve BKAY}

Dünyada kentlerin küresel çapta ön plana çıkma çabası, planlama sorunlarının boyutlarının sınırları aşması ve çeşitlenmesi ile ekonomik, politik, ideolojik, sosyal ilişkilerin yeniden yapılanması, farklı devlet kurumları arasında iletişim kanallarının açılması, özel sektör ile kamu sektörünün mekansal planlama sorunlarını kolektif şekilde çözümlemeye çalışarak mekansal gelişimi desteklemesi, karar verme süreçlerinin çok boyutlu ve çok aktörlü hale gelmesiyle karmaşıklaşması ve bu nedenle çok düzeyli yönetişimin önem kazanması, geleneksel planlama yaklaşımlarının politik ve bürokratik sebepler yüzünden bölgesel ve kentsel problemlere çözüm üretmekte yetersiz kalması ile mekansal planlamanın rolünün yeniden tanımlanması ihtiyacı ortaya çıkmıştır (Albrechts ve Balducci, 2013; Albrechts, 200I). İşte bu noktada, daha esnek, çok sektörlü ve çok aktörlü katılıma imkan veren, uygulama ve sonuç odaklı, kolektif çalışma ve eylem planları ile insanları harekete geçiren yeni yönetişim şekli sunan stratejik mekansal planlama yaklaşımı ile farklı bir planlama kültürü oluşturulma yönünde çalışılmıştır. Stratejik planlama, daha çok işletme ve yönetim yaklaşımlarının bir olgusuyken, bu yaklaşım mekansal bir nitelik kazanarak, bölgesel ve kentsel problemlerin mekansal değişimi sağlayacak süreçlerini de etkilemek üzere adapte edilmiştir. Healey (20I3) aslında planlamanın doğası gereği stratejik olduğundan bahsetmekte; strateji belirlemenin geleneksel planlamada da her zaman yeni kapasiteler yaratma ve olanaklar sağlama açısından yol gösterici olduğunu vurgulamaktadır.

Stratejik mekansal planlama bölgesel gelişme için uzun vadeli planlama ile eşleşmektedir ve yönetişim için farklı ölçeklerde yeni kurumsal örgütlenme biçimleri gerektirmektedir (Friedmann vd., 2004). Bu yeniden yapılanma, farklı seviyelerdeki devlet kurumlarının birlikte çalışmasını, çok düzeyli yönetişimi desteklemektedir. Birçok ülkede devlet kurumlarının stratejik mekansal planlama yaklaşımını benimsediği, kentsel ve bölgesel gelişimi bu yaklaşım ile desteklediği görülmektedir. Bu planların uygulamadaki başarısının ise kurumsallaşmanın ve kurumlar arası işbirlikleri ile güvenin sağlandığı ülkelerde daha yüksek olduğu söylenebilir (Percoco, 20I6; Albrechts, 200I).

Türkiye'de stratejik mekansal planlamanın ilk kez 7. Beş Yıllık Kalkınma Planı'nda ele alındığı, daha sonra 2000 yılında Uzun Vadeli Strateji Belgesi ve 8. Beş Yıllık Kalkınma Planı'nda gündeme geldiği görülmektedir. Bu belge ve planların ardından stratejik planlama konusuna 2004 yılında 5216 Sayılı Büyükşehir Belediyesi Kanunu'nda yer verilmiş; daha sonra 2005 yılında kabul edilen 5302 sayılı İ Özel İdaresi Kanunu'nda ku-

\footnotetext{
https://csb.gov.tr/sss/butunles-ik-kiyi-alanlari-yonetimi-ve-planlamasi (erişim tarihi: 15/0I/2019).
} 
rumsal strateji oluşturmak valinin görevleri arasında sayılmış, İçişleri Bakanlığı'nın 5272 sayılı ve 5216 sayılı kanunlarında da DPT stratejik planları hazırlamak ile yükümlü kılınmıştır (Sınacı ve Büyükgöçmen Sat, 2016). 2006 yılında yürürlüğe giren 9. Beş Yıllık Kalkınma Planı (2007-20I3)'nda ise temel beklentiler eylem programlarının etkin olarak kullanılması, izleme mekanizmasının kurulması ve yasalar ile kurumsal düzenlemelerin yapılması olarak belirlenmiş; daha sonra ilgili mevzuatın ve yetki dağılımının yapılmasında 201 I yılında kurulan ÇŞB görevlendirilmiştir.

Bugün Türkiye'de Mekansal Planlar Yapım Yönetmeliği'nin² 6. maddesi 6. ve 7. bendlerinde BKAY'ın, uzun devreli gelişme planı, ulaşım ana planı ve diğer özel amaçlı plan ve projeler gibi 'mekansal planlama kademelenmesinde yer almayan, planlara girdi sağlayan ve imar planı kararlarına veri oluşturan veya gerektiğinde mekansal planların uygulanmasına yönelik araç ve ayrıntıları da içerebilen, stratejik plan yaklaşımı ile gerektiğinde şematik ve grafik planlama dili kullanılarak yapılan, plan paftası, eylem planı ve planlama raporu ile bütün olan çalışmalardır' ifadesiyle bir stratejik mekansal plan olarak görüldüğünü söylemek mümkündür. Bu yönüyle bu planlar, stratejik mekansal planlama yaklaşımına da paralel olarak yukarıdan aşağıya hiyerarşik planlama sisteminin ve sektör bazlı planlama şeklinin örnekleridir; bu nedenle entegrasyon, sektörler arası koordinasyon, yönetim konuları ön plana çıkmaktadır (Özügül vd., 2017). Olumlu yanları, kurumları planlı hareket etmeye sevk etmesi, sistematik bir hedef, zaman ve maliyet ilişkisinin kurulması, faaliyetlerin belli bir zaman aralığında gerçekleştirilmesini desteklemesi olarak da belirlenmiştir (Sınacı ve Büyükgöçmen Sat, 2016). Ancak, genel olarak değerlendirildiğinde, Türkiye'de stratejik mekansal planların süreçlerinin belirsizliği ve yetki karmaşası nedeniyle etkin şekilde kullanılamadı̆̆ı görülmektedir (Eraydın, 2008). Ayrıca, planlama çalışmalarının merkezileşmesi, merkezi ve yerel yönetimler tarafından katılımcı yaklaşımın benimsenememesi, kurumların özerkliklerini yitirmesi, çevresel etki değerlendirme süreçlerinin yok sayılması ve planların uygulanamaması gibi olumsuz faktörler de stratejik mekansal planların etkisiz kalmasına neden olmaktadır. Bu kapsamda, BKAY ve planlarının da stratejik mekansal planlar olarak Türkiye'ye özgü bu özellikleri gösterdiği söylenebilir.

1960'lı yıllarda sektörel planlamanın ön plana çıkması ile birlikte planlama kurum ve kuruluşlarının sayısının ve yetki alanlarının fazlasıyla arttığı görülmektedir. Kıyı alanlarının ve kaynaklarının da bu yıllarda üretim ve fayda sağlamanın odağında kaldığı söylenebilir (Carter vd., 20I5). 1970'li yıllar dünyada çevre bilincinin oluşmaya başladığı ve kıyı alanlarının artık korunması gerekliliğinin gündeme getirildiği, 1980'li yıllar ise dünyada ve Türkiye'de artık sektörel planlamanın hedeflenen başarıyı getirmediğinin tartışıldığı, daha bütüncül yönetim şeklinin ge- lişmesinin istenildiği, bu nedenlerle de kıyı alanları açısından önemli gelişmelerin olduğu yıllar olmuştur. 1990'lı yıllardaki en önemli gelişme, dünyada stratejik mekansal planlama yaklaşımının önem kazanmasının da etkisiyle uygulamaya yönelik olarak hazırlanan pilot çalışma niteliğindeki kıyı alanları yönetimi projeleridir. Bu projeleri, özellikle 1992 yılında gerçekleştirilen Rio Konferansı sonucunda ortaya çıkan Gündem 2 I Belgesi'nin kıyı alanları yönetimine getirdiği yeni ve kapsayıcı yaklaşımların yansımaları olarak değerlendirmek olanaklıdır. ${ }^{3}$ Bu yaklaşım yerel düzeyde, farklı amaç, yöntem ve ölçeklerde birbirinden bağımsız olarak farklı kurum ve kuruluşların eşgüdümünde yürütülmüş olan projelerin kıyı alanlarında birbirleriyle daha ilişkili bir yönetim planı hazırlanarak uygulanması önerisini getirmiştir. Böylece, kurumsal ve stratejik bir yapılanma modeli ile kıyı alanlarında uygulamalar yapılmaya başlanmıştır. Bu modelde sürdürülebilir gelişme stratejik bir yaklaşım ile anahtar kavram olarak ön plana çıkmaktadır (Enemark, 2005). 1994 yılında Avrupa Birliği'nin kurulması ile birlikte Avrupa'daki kıyı kentleri nüfus artışı ve kıyı alanlarındaki altyapının gelişimi ile kıyı alanlarında sosyal ve çevresel sorunlar ile karşı karşıya kalınmıştır; bu nedenle, Avrupa Birliği BKAY için yeni bir yönetim şekli önermiştir (CEC, 2002). Bu belge incelendiğinde göze çarpan en önemli konular kıyı alanlarının bağımlılıklarının, farklılıklarının, yerellik ve çeşitliliklerinin, eko-sistem ile ilişkilerinin adaptif bir yönetim şekli ve tüm idari birimlerin katılımı ile koordine edilmesi gerekliliğidir. Ulusal stratejiler belirlenirken de idari birimlerin yönetimdeki rolünün belirlenmesi, uygulamada farklı plan araçlarının kullanılması, sürece dahil olan kurumsal ve kurumsal olmayan tüm kullanıcılar ile ilişki kurulması ve bölgesel gelişim mekanizmaları ile ekonomik planlar yapılması gerekliliği vurgulanmıştır (CEC, 2002; Post ve Lundin, 1996).

BKAY sektörel planların ya da yönetim sistemlerinin yerini alacak bir yönetim planı değildir. BKAY, kıyıların diğer arazi kullanım ve etkinliklerle entegre, adaptif ve ekosistem temelli bir şekilde yönetilebilmesi için gerekli bir araç olarak sadece doğal kaynakların değil, kıyıda yaşayan toplulukların, çeşitli işletmelerin ve endüstriyel faaliyetlerin tarafların koordineli ve uzlaşmacı yaklaşımlarıyla yönetilmesini hedeflemektedir (Carter vd., 2015; Christie, 2005). Hem aşağıdan yukarıya planlama hem de yukarıdan aşağıya planlama yaklaşımları tasarlanarak çok sektörlü, katılımcı ve çatışmaları yöneten bir şekilde yerel ve merkezi yönetimler arasında denge kurulması özellikle önemlidir. BKAY ile ilişkili olarak incelenen doğal kaynakların yönetimi konusunda vurgulanan en temel olgu doğal kaynak alanlarının birbirleriyle ilişkili olarak yönetilmesi, tüm seviyelerdeki kamu kurum ve kuruluşlarının koordineli olarak sürece dahil edilmesi ve hem gelişmiş hem de gelişmekte olan ülkelerin kıyı alanlarını kapsayan uluslararası ölçekte de kıyı alanlarının bütüncüllüğünü koruyacak adaptif (koruma, ye-

\footnotetext{
https://webdosya.csb.gov.tr/db/e-plan/webmenu/webmenu 13088.pdf (erişim tarihi: 14/02/2019).
}

3 https://eur-lex.europa.eu/eli/reco/2002/413/oj (erişim tarihi: 15/04/2019). 
nileme, sakınım, telafı planları gibi planlarla), uzun vadeli bir yönetim anlayışının geliştirilmesidir (Mojica Velez vd., 20।8). Zonlama, kıyı kenar çizgisinin belirlenmesi, havza yönetimi, özel alan planlaması, gelişimin kontrolü ve kıyı alanlarındaki izinler BKAY kapsamında tüm kıyı alanlarında, gerektiğinde uluslararası işbirlikleriyle de dengeli bir biçimde planlanmalıdır.

Carter vd. (20I5)'nin beş ülkeyi inceleyerek yaptığı analize göre, BKAY özellikle dışsal finansal olanaklarının fazla olduğu ve tüm ilgili kurum ve kuruluşların uzun vadeli taahhütü ile esnek bir planlama anlayışı ile ele alındığında başarılı olmakta; gelişmiş ülkelerde BKAY ile ilişkili sektörel plan ve programların olması ve kuralların kıyı alanlarının dengeli gelişimine odaklanmış olması bu ülkelerde başarılı BKAY ve planlarının gerçekleşmesine neden olmaktadır. Öte yandan, gelişmekte olan ülkelerde ise üretim ihtiyacı kaynakların tüketilmesi odaklı bir yaklaşım ile karşılaşılmasına neden olmaktadır (Christie, 2005). Bu açılardan bakıldığında BKAY'ın Türkiye'de de üretim odaklı ve kamunun değil, tüm ilgili kurum ve kuruluşların çıkarları kapsamında geliştiğini söylemek mümkündür.

\section{Türkiye'de Kıyı Alanlarının Durumu ve Başlıca Sorunları}

Türkiye, sahip olduğu kıyı alanları açısından, kıtalararası ulaşım bağlantılarını sağlayan deniz yollarının geçiş noktaları, enerji iletim hatları, ihracat limanları, turistik tesisler gibi kullanımların yanı sıra İstanbul ve Çanakkale boğazlarının konumu ile jeopolitik olarak stratejik bir konumdadır. Ayrıca, kıyı alanları iklim özellikleri, ekosistem ve biyolojik çeşitlilik ile de tarımsal etkinlikler ve doğal değerler açısından zengin alanlar olmuştur. Uluslararası ölçekte özel çevre koruma bölgeleri, sit alanları, milli parklar, tabiat koruma alanları, sulak alanlar gibi çok sayıda doğa koruma alanına ev sahipliği yapmaktadır.

Türkiye'deki kıyı alanlarını, taşıdığı bölgesel farklılıklar nedeniyle ekolojik, ekonomik, morfolojik, meteorolojik, sosyoekonomik, kültürel açılardan ya da arazi kullanım biçimleri, nüfus yoğunluğu ve sektörel yoğunlaşma gibi açılardan da incelemek olanaklıdır. Türkiye, Akdeniz Havzası ülkeleri arasında Yunanistan ve İtalya'nın ardından en uzun kıyı çizgisine sahiptir. ${ }^{4} \mathrm{~K}$ ıyı kentlerinde nüfus yoğunluğunun fazla olması sebebiyle de Türkiye nüfusunun yaklaşık \%54,5'i kıyılarda yaşamaktadır (Kurt, 20I5). 8I ilden 28(\%35)'inin denize kıyısı bulunmakla birlikte, bölgesel özellikler ve etkileşimlere göre kıyı alanlarındaki mevcut faaliyetlerin etkilerinin iç bölgelerde de izlendiği görülmektedir. Kıyı alanlarında yer seçen kullanımlar genelde kentsel ve kırsal yerleşim alanları, turizm alanları, endüstri ve depolama alanları ile balıkçılık ve su ürünleri üretimi, deniz ulaştırması ve enerji gibi sektörlerdir. Kıyı alanları tanımı deniz dışında, göl ve nehirleri de kapsamaktadır; ancak bu su kaynakları ile ilişkili kıyı alanları politikaları ve yönetimi kapsamında kapsamlı bir yaklaşım geliştirilmemiştir. Bu nedenle, bu alanlar denizlerden de daha korunmasız durumdadır ve çok çeşitli sorunlarla karşı karşıya kalmaktadır. Bu sorunların başında son yıllarda sayı olarak artmış olan, ${ }^{5}$ su kaynaklarının su rejimini azaltan, akarsu çevresindeki fauna ve floraya olumsuz etkileri bulunan hidro elektrik santralleri (HES'ler) gelmektedir. Son yıllarda artan enerji ihtiyacını karşılamak sebebiyle kurulan bu HES'ler deniz dışındaki su kaynakları ve çevrelerine büyük zarar vermektedir.

Türkiye'deki kıyı alanları sorunlar açısından da farklı olumsuzluklarla karşı karşıya kalmaktadır. Kıyı alanlarında yaşanan sorunların en önemli üç kaynağını kentleşme, turizm etkinlikleri ve endüstriyel kullanımlar olarak saymak olanaklıdır. 1960’lı yıllarda kırdan kente olan göç hareketleri sonucunda görülen hızlı ve plansız kentleşme ile kaçak yapılaşma nedeniyle çevre sorunlarından en çok etkilenen alanlar kıyı alanları olmuştur. Ayrıca enerji, ulaştırma ve konut sektörlerinde gerçekleşen son dönemdeki değişiklikler ile kıyı alanları büyük baskı altında kalmıştır. Karadeniz ve Akdeniz kıyılarında konumlanan nükleer santraller, kıyı alanlarının doldurulması, İstanbul gibi şehirlerdeki büyük gayrimenkul ve ulaştırma projeleri, kıyılardaki alanları da içeren kentsel dönüşüm projeleri kıyı alanlarında geri dönüşü olmayan tahribata ve çevre kirliliğine sebep olmaktadır.

1980'li yıllarla beraber artan turizm faaliyetleri ile kıyılarda kitle turizmi teşvik edilmiş ve daha fazla kıyı alanı yapılaşmaya açılmıştır. Turizm etkinlikleri için imara açılan kıyı alanlarında, çok sayıda turistik tesis yapılmış, ikinci konutların da artış göstermesi ile bu alanlar kentsel gelişim baskısı altında kalmıştır. Öte yandan, ulaşım kolaylığı konumun avantajlarından yararlanma nedeniyle kıyı alanlarında yer seçen ağır endüstri tesisleri ile bu tesislere hizmet veren yapı ve tesisler (liman ve boru hatları gibi), su kirliliğine ve kıyı kaynaklarının zarar görmesine yol açmıştır. İnsan etkisi ile ortaya çıkan bu sorunların yanı sıra doğal koşullarla gerçekleşen erozyon, sel ve deprem gibi doğal yıkım olayları ile son yıllarda küresel gündemi oluşturan iklim değişikliği de önemli sorunlar arasındadır.

Türkiye'de kıyı alanlarında yaşanan tüm bu sorunların temelinde, ekonomik getiri için yapılan faaliyetlerin çevresel değerler üzerinde yarattığı olumsuz etkiler de görülmektedir. Kıyı alanlarının ekosistem temelli bir yaklaşım ile, katılımcı bir yönetişim sistemi, farklı ölçek ve sektörlerdeki kurumlar arasında eşgüdüm sağlanarak, yerel özellikler ön plana çıkarılarak sürdürülebilir yönetim anlayışı (UNEP/MAP, 20I2) ile planlanması gerekmektedir. Bu anlayışın temel özellikleri stratejik mekan-

\footnotetext{
4 http://www.webcitation.org/query?url=https\%3A\%2F\%2Fwww.tr.wikipedia.org\%2Fwiki\%2FK\%25C4\%25 BIy\%25C4\%25BI_uzunluklar\%25C4\%25BIna_g\%25C3\%25B6 re_\%25C3\%25BClkelerin_listesi\&date=2017-04-I I (erişim tarihi: I I/04/2017).

52017 yılı sonu itibari ile 620 adet Hidro Elektrik Santrali işletilmektedir (dsi.gov.tr (erişim tarihi: 15/05/2019).
} 
sal planlama ile örtüşmektedir. Böylece, çeşitli arazi kullanım stratejileri, eylem planları ve programları da üretilerek mekansal parçalanma yerine bütünleşme sağlanabilmelidir.

Türkiye'de kıyı alanlarının yönetimi ve planlanmasında yaşanan sorunların başında stratejik mekansal planlama ile de ilişkili olarak kıyı alanları yönetimine ilişkin ulusal bir vizyonun ve kıyı politikasının olmayışı gelmektedir. Bunun yanı sıra; çevre duyarlı bir yaklaşımın olmaması, çok sayıda ve farklı yasal düzenlemelerin karmaşıklığa yol açması, kurum ve kuruluşlar arasında yetki karmaşasının yaşanması, farklı sektörler arasında yaşanan yer seçimi çatışması, parçacı ve talebe yönelik imar planlama çalışmaları, etkin bir izleme ve değerlendirme sisteminin olmaması, uygulamada denetim ve yaptırım mekanizmasının etkin işletilememesi, yönetim süreçlerine halkın ve sivil toplum kuruluşlarının katılımını sağlayacak mekanizmaların yetersiz olması, kamu ve toplum düzeyinde farkındalığın yetersiz olması gibi etkenleri çoğaltmak olanaklıdır. Bu nedenle, kıyı alanlarının yönetimi ve planlanmasında stratejik mekansal planlamanın gerekleri de yerine getirilerek, ortak bir vizyon çerçevesinde bütünleşik bir biçimde, hem farklı düzeydeki kurum ve kuruluşları kapsayan hem de uygun siyasal ve yasal düzenlemelerle, katıIımcılığı destekleyen çözüm önerileri getirilmesi gerekmektedir.

\section{Türkiye'de Kıyı Politikaları ve Kıyı Alanları Yönetimi}

Türkiye'de özellikle son 40 yılda kıyı politikaları ve kıyı alanları yönetiminde gelişmelerin yaşandığı görülmektedir. 1950’li yıllara kadar kıyı alanları, gelişmelerden fazla etkilenmemiş, 1950'li yıllardan sonra ise kırdan kente göç ile çarpık kentleşme ortaya çıkmış, ancak kıyı alanlarında turizme yönelik etkinliklerin daha başlamamış olması nedeniyle kıyı alanlarına yönelik baskı bugüne göre daha az düzeyde olmuştur (Köroğlu, 2013). Ancak, 1960'lı yıllar iç turizm hareketleri ile birlikte Marmara, Ege ve Akdeniz kıyı alanlarının özel ve kamu kuruluşları tarafından kullanıldığı bu dönem kamuoyunda kıyı yağması olarak anılmaktadır (Keleş, 2008).

Stratejik mekansal plan olarak görülen BKAY ve planlaması ile ilgili girişimlerin, çok sektörlü ve çok aktörlü olarak farklı düzeylerde tasarlandığını söylemek mümkündür. Bu girişimlerin, uluslararası kuruluşların mali desteği ile sivil toplum kuruluşlarının sorumluluğunda, uluslararası sözleşmelerin gereği olarak ilgili bakanlıklar tarafından başlatıldığı görülmektedir. Türkiye'de uygulamaya yönelik ilk örnekler olması nedeniyle pilot çalışma niteliğindeki bu projelerin sonuçları incelendiğinde; bazılarının bir araştırma raporu ve veri toplama aşamasında kaldığı, bazıları için ise yönetim planı hazırlanarak uygulamaya yönelik politika ve stratejiler geliştirildiği görülmektedir (Gülbitti, 20l7).
Tüm bu girişimler kurumsal yapılanmayı ve ilgili program, plan ve strateji paketlerinin de geliştirilmesini desteklemiştir. Diğer bir deyişle, kıyı kurulu, vakıf, şirket, yönetim birliği gibi yönetsel yapıya ilişkin yeni ve somut önerilerde bulunan ya da mevcut yönetim yapısı için öneriler getiren bu girişimler ile stratejik mekansal planlamanın da öngördügü gibi kurumlar arası eşgüdüm ve kurumsallaşmaya önem verildiği ve bu bağlamda hazırlanan eylem planları ve raporlarla desteklendiği sonucuna ulaşmak olanaklıdır. Bu dönemde, kıyı alanları yönetimi konusunda önemli bir belge niteliğinde olan ve Türkiye'de sürdürülebilir kalkınmanın sağlanması için çevre ile ilgili stratejilerin ortaya konulması, önceliklerin belirlenmesi ve yatırım kararlarının alınmasına yönelik çevre politikalarının oluşturulması amacıyla Ulusal Çevre Eylem Planı (UÇEP) ve bu kapsamda 1997 yılında Arazi Kullanımı ve Kıyı Alanlarının Yönetimi Raporu hazırlanmış (Duru, 2003; DPT, 1997); Kıyı Alanları Yönetiminin Geliştirilmesi konulu bir proje hazırlanarak kıyı alanlarındaki çevresel sorunların belirlenmesi, kıyılardan yararlanan kesimlerin karar alma süreçlerine katılması için yönetim modellerinin geliştirilmesi; bu yönetim modellerinin gerçekleştirilmesi için gerekli yasal düzenlemelerin ve kıyı alanları yönetimi eylem planlarının hazırlanması ve uygulanması gibi önemli noktalara değinilmiştir (Görer ve Duru, 200I). Projenin uygulayıcısı Bayındırlık İskan Bakanlığı, ilgili taraflar ise Turizm Bakanlığı, Çevre Bakanlığı, yerel yönetimler ve il özel idareleri olarak belirlenmiştir. UÇEP ile kıyı alanları yönetimi konusunda bütünleşik yaklaşımların benimsendiği görülmekle birlikte kıyı alanları daha çok çevrenin korunması bağlamında ele alınmıştır. Planda yer verilen ilke ve eylemler incelendiğinde, dönem itibari ile kıyı alanları yönetimi konusunda önemli bir belge olduğu görülmektedir. Yine de genel olarak bu girişimlerin, yasal altyapı olmaması nedeniyle, uygulama olanağı ve yaptırımı olmayan çalışmalar olarak kaldığı; ancak, yol gösterici niteliği olduğu görülmektedir.

1990’lı yıllar, aynı zamanda kıyı alanları yönetiminin ele alındığı sivil kurumsal yapılanmaların da ortaya çıktığı yıllar olmuştur. Türkiye'de kıyı alanları yönetimi ve planlamasına yönelik kurumsal anlamda atılan ilk ve en önemli adım, 1993 yılında Kıуı Alanları Yönetimi Türkiye Milli Komitesi (KAY-TMK)'nin kurulmasıdır. Komitenin kıyı alanlarından çeşitli kullanımlar arasında denge sağlanarak yararlanılması ve korunması çalışmalarını desteklemek; kıyı ile ilgili kamu kuruluşları, üniversiteler, belediyeler, sivil toplum kuruluşları ve özel sektör arasında bilgi alışverişi ve işbirliği yapılmasını sağlamak; bilimsel araştırma projelerinin oluşturulmasına katkıda bulunmak, katılmak, desteklemek, toplantılar düzenlemek ve yayın yapmak; kıyı alanları yönetimine katkıda bulunacak bilgi ve verilerin toplandığı bir merkez oluşturmak; kıyı kullanım sorunlarını tanımlamak, incelemek, izlemek, çalışmalar yürütmek ve bu çalışmaları desteklemek; kıyı alanları ile ilgili diğer ülkelerdeki gelişmeleri izlemek, Türkiye'de kıyı alanları yönetimi için ilke ve kurallar önermek, yasaların ve yönetim biçimlerinin oluşmasına, planlama 
kararlarının uluslararası standartlara uyumlu kılınmasına katkıda bulunmak; uluslararası kuruluşlarla işbirliği yapmak, üye olmak, yürütülen program ve projelere katılmak; kıyı alanları yönetimi ile ilgili eğitim programlarının geliştirilmesine katkıda bulunmak gibi amaçları bulunmaktadır (Eke, 1995).

Bir diğer önemli girişim ise, Akdeniz ve Karadeniz kıyılarında, deniz ve kıyı alanlarının korunması ve kıyı yönetimi uygulamalarının geliştirilmesi amacıyla 1993 yılında kurulan Akdeniz Kıyı Vakfı'dır. Kurumlar ve kişiler arasındaki bilimsel ve mesleki işbirliğinin geliştirilmesini sağlamayı hedefleyen uluslararası bir araştırma kurumu niteliğinde olan Vakfın amacı, Akdeniz ve Karadeniz'in kıyı ve deniz ortamında yer alan fiziksel, biyokimyasal ve ekolojik süreçler ile bunların etkileşimlerini anlamak, bütünleşik kıyı ve deniz alanları yönetiminin gerçekleştirilmesi doğrultusunda bilimsel bilgilerin, verilerin ve çağdaş yönetim araçlarının kullanılmasına katkıda bulunmak (konferanslar, eğitim programları, yayınlar, bültenler) ve Akdeniz Eylem Planı ve Karadeniz Stratejik Eylem Planı gibi mevcut uluslararası çabalara katkıda bulunmaktır. ${ }^{6}$ Akdeniz Kıyı Vakfı, BKAY konusunda hem uluslararası ölçekte hem de Türkiye'de BKAY konusunda doğrudan çalışmalar yürüten sivil toplum kuruluşu niteliğinde olması açısından önemli bir girişimdir.

2000'li yıllar, küreselleşme ile birlikte yabancı sermayenin önem kazanması ve kentsel mekanda etkili olması ile deniz trafiğinin artması ve rant odaklı gelişimin egemen olması nedeniyle, başta İstanbul olmak üzere kıyı alanlarında çok sayıda projenin ortaya çıtığı bir dönem olmuştur (Köroğlu, 20।3). Kıyı alanlarında daha da artan turizm yapıları ve ikinci konutların yanı sıra liman, iskele, rıhtım, karayolu, köprü gibi denizcilik ve ulaştırmaya yönelik kıyı yapıları ve enerji santralleri de artış göstermiş, özellikle son yıllarda yoğun bir biçimde görülen konut arzı ve altyapı projeleri ile de kıyı alanları üzerindeki baskı artmıştır. 2007 yılından bu yana, doğrudan devlet eliyle başlatılan BKAY ve planlama çalışmaları günümüzde halen Çevre ve Şehircilik Bakanlığı tarafından yürütülmektedir. Ancak sektörel olarak da BKAY Kültür ve Turizm Bakanlığı, Ulaştırma, Denizcilik ve Haberleşme Bakanlığı, Orman ve Su İşleri Bakanlığı, Gıda, Tarım ve Hayvancılık Bakanlığı, Maliye Bakanlığı, Genel Kurmay Başkanlığı, Sağlık Bakanlığı, İ Özel İdareleri, Büyükşehir ve İlçe Belediyeleri gibi birçok kurum ve kuruluşla ilişkilidir. Hiyerarşik olarak BKAP sektörel planlar ile mekansal planlar arasında bir plan olmak ile beraber Mekansal Planlar Yapım Yönetmeliği'nde tüm sektörel faaliyet ve planları içerecek şekilde olduğu belirtilmiştir. BKAP tanımı yapılmış ve bu planın stratejik planlama yaklaşımı çerçevesinde, şematik, mekansal planlama kademelenmesinde yer almayan ve diğer planlama çalışmalarını yönlendirici nitelikte olduğu belirtilmiştir. Türkiye'de BKAY ve BKAP mekansal bir plan dilinde ve hükmünde olmayan, yasal olarak güçlenmekle birlikte yaptırım açısından eksik bir plan türü olarak yürürlük kazanmıştır. Ayrıca, Türkiye'de kıyı alanları ile ilgili denizcilik, balıkçılık, turizm vb. sektörlere yön vermek amacıyla oluşturulan çok sayıda rapor ve master planlar da bulunmaktadır (Ulaştırma Kıyı Yapıları Master Planı, Turizm Kıyı Yapıları Master Planı, Balıkçılık Master Planı ve Tersaneler Master Planı gibi). Bu belgeler doğrudan ilgili sektör yatırımlarına yönelik hazırlansa da, bazılarında BKAY ve planlaması yaklaşımının önemine vurgu yapıldı̆̆ görülmektedir.

Türkiye'de BKAY, uluslararası gelişmelerin etkisiyle hedefleri ve kapsamı sürekli gelişen ve değişen bir konu durumundadır. Bu nedenle, kıyı alanlarında yaşanan sorunların yanı sıra gelişmeye yön vermesi beklenen yönetsel gereksinimlerin ortaya konulması gerekmektedir. Türkiye'de henüz BKAY konusunda yatay ve dikey kurumsal bütünleşmeyi sağlayan bir organizasyona sahip olmadığı görülmektedir. Bunun için kurumlar arası eşgüdümü sağlayacak öncü bir yapılanmaya gereksinim vardır. Bu bölümde, bu konuyla ilişkili olarak yasal, kurumsal düzenlemeler ile planlama yönünden yapılan değişiklikler açıklanmaktadır.

\section{I. Yasal Düzenlemeler}

Türkiye'de kıyı alanları ile ilişkili olarak 1972 yılında gerçekleştirilen Stockholm İnsan ve Çevre Konferansı'nın etkisiyle yasal düzenlemeler yapılmıştır. Aynı yıl çıkarılan 1605 sayılı (6785 sayılı) İmar Kanunu'nda Bazı Değişiklikler Yapılması Hakkında Kanun'un ek maddeleri ile deniz, göl ve nehir kenarlarındaki alanlarda yapılaşma koşulları ile ilgili hükümlere yer verildiği, ancak bu maddelerde kıyı ya da kıyı alanı gibi kavramlara yer verilmediği görülmektedir. İlk kez 1982 Anayasası'nda doğrudan kıyı alanları ile ilgili hükümlere yer verilmiştir. Anayasa'nın 43. maddesinde "Kıyılar, Devletin hüküm ve tasarrufu altındadır. Deniz, göl ve akarsu kıyılarıyla, deniz ve göllerin kıyılarını çevreleyen sahil şeritlerinden yararlanmada öncelikle kamu yararı gözetilir. Kıyılarla sahil şeritlerinin, kullanılış amaçlarına göre derinliği ve kişilerin bu yerlerden yararlanma imkan ve şartları kanunla düzenlenir" hükmü ile kıyı alanları anayasal güvence altına alınmıştır. ${ }^{7}$ Kıyı alanlarının hukuki statüsünün bir çerçeveye oturtulması, bu alanların yasal dayanağının güçlendirilmesini sağlamış ve bu alanların kullanımında kamu yararının gözetilmesini ön plana çıkarmıştır.

Anayasa'nın bu maddesine dayanılarak 1984 yılında çıkarılan 3086 sayılı Kıyı Kanunu, yalnızca kıyı alanlarına özgü ilk yasal düzenlemedir. Bu Kanun ile ilk kez kıyı alanları ile ilgili kapsamlı düzenlemeler yapılmış, I 986 yılında kamu yararına aykırı biçimde düzenlenmiş olması gerekçesiyle dava açılmış, bunun üzerine Anayasa Mahkemesi önce Kanunun bazı maddelerinin

\footnotetext{
6 Components of MEDCOAST. Mediterranean Coastal Foundation.URL: http://www.webcitation.org/query?url=https\%3A\%2F\%2Fwww.medcoast.net\%2Fmodul\%2Finde x\%2Fmenu\%2FAims\%2FI2\&date=20I7-04-I I (erişim tarihi: II/04/20I7).

7 T.C. Resmi Gazete. (02/04/20 13). Kıyı Kanununun Uygulanmasına Dair Yönetmelikte Değişiklik Yapılmasına Dair Yönetmelik. 28606.
} 
iptal edilmesine karar vermiş, sonrasında bu maddelerin iptali ile Kanunun diğer hükümlerinin de uygulanamayacağı gerekçesiyle Kanunun tümünün iptaline karar vermiştir. 1990 yılına kadar kıyı alanlarına ilişkin herhangi bir yasa olmadan uygulamalar yapılmaya devam edilmiştir.

Aynı dönemde, 1982 yılında çıkarılan 2634 sayılı Turizm Teşvik Kanunu ile Bakanlar Kurulu tarafından belirlenen kültür ve turizm koruma ve gelişim bölgeleri ile turizm merkezlerinde, her ölçekte plan yapmaya, yaptırmaya ve onaylamaya Kültür ve Turizm Bakanlığı yetkili kılınmıştır. ${ }^{8}$ Bu Kanun ile kıyı alanlarında turizme yönelik kullanımlar, günübirlik turizm alanları ve sahil şeridi dışındaki konaklama tesislerinin devamı niteliğinde olan yapı ve tesisler için hazırlanan imar planları onaylanarak yürürlüğe girmiş ve devletin hüküm ve tasarrufunda olan kıyı alanları, kıyı turizmine turistik tesis kazandırılması amacıyla uzun süreli olarak yatırımcılara tahsis edilmiş, kıyı alanlarındaki yapılaşmanın önü açılmıştır.

Dönemin önemli diğer bir gelişmesi olarak 1985 yılında çıkarılan 3194 sayılı İmar Kanunu ile yerel yönetimlere imar planlama yetkisi verilmesi ile kıyı alanlarında yapılaşma hızlı bir şekilde artmıştır. Belediye ve mücavir alan sınırları içinde ve dişında kalan yerlerde yapılacak planlar ile inşa edilecek resmi ve özel bütün yapılar bu Kanun hükümlerine bağlı olarak düzenlenmektedir.9 362 I sayılı Kıyı Kanunu kapsamındaki sahil şeridinin bitişiği durumundaki arka alanlarda yapılacak imar planı ve yapıların İmar Kanunu'na göre düzenlendiği göz önünde bulundurulduğunda, kıyı alanlarını etkileyen en önemli yasal düzenlemelerden biri olduğu görülmektedir. Örneğin, bir yerleşim alanı için hazırlanacak bir imar planının kıyıya kadar olan bölümü İmar Kanunu, kıyı alanındaki bölümü ise Kıyı Kanunu hükümleri doğrultusunda biçimlenmektedir. Bu nedenle, kıyı alanı ile devamı niteliğinde kara yönündeki arka alanının, alansal olarak bütünleşmesinin ne ölçüde sağlanabildiği tartışma konusu olmaktadır.

Kıyı alanları yönetimini ilgilendiren bu kadar çok ve farklı yasal düzenlemenin yürürlükte olması ile de birtakım sorunlar yaşanmaktadır. Bunun en önemli nedeni ise, kıyı alanlarını ilgilendiren herhangi bir alanda bir yasal düzenleme hazırlanırken başka bir alanın konusu olabilecek hususların göz ardı edilmesidir. 1980 sonrası dönemdeki yasal düzenlemelerin çıkarılması, iptal edilmesi ve değiştirilmesine ilişkin süreçler incelendiğinde, kıyı alanlarındaki karmaşık yapının ve sorunların başlangıç nedenleri görülmektedir. Örneğin, 1984 yılında çıkarılan 3086 sayılı Kıyı Kanunu'nun iptali sonrası dönemde yeni kanun yapılana kadar geçen uzun sürede, Turizmi Teşvik Kanunu'nun etkileri daha da çok görülmüş ve kıyı alanları zarar görmüştür.

1990'lı yıllarla beraber kıyı alanları yönetimi ve planlaması çalışmalarına verilen önem daha da artmıştır. 1990'da yürürlüğe giren ve aynı yıl Uygulama Yönetmeliği de çıkarılan 362। sayılı Kıуı Kanunu, kıyı alanlarının planlanması konusunda temel yasal düzenleme olarak halen yürürlüktedir. 362 I sayılı Kanunun 3086 sayılı Kanuna göre daha kapsamlı olduğu görülmektedir. İki kanun arasındaki en önemli farklııı, kıyı kuşağı derinliğinin belirlenmesi konusudur. Kıyı kuşağı, 3086 sayılı Kanunda kıyı kenar çizgisinden itibaren kara yönünde, imar planlı yerlerde yatay olarak en az 10 m, diğer yerlerde en az 30 m genişliğinde bir alan olarak belirlenmiştir. ${ }^{10} 3621$ sayılı Kanunda ise, 1992 yılında yürürlüğe konulan 3830 sayılı Kıyı Kanunu'nda Değişiklik Yapılmasına Dair Kanun ile sahil şeridi, tüm kıyılar için farklılık gözetmeksizin yatay olarak en az $100 \mathrm{~m}$ alan olarak tanımlanmıştır." 362 I sayılı Kıyı Kanunu ve Uygulama Yönetmeliği yürürlüğe girdiği tarihten bu yana çok sayıda değişikliğe uğramıştır. Kıyı gibi geniş bir alan içeren bir tanımın adıyla çıkarılan yasal düzenlemelerin temelini, ağırIıkla mekansal planlama yoluyla yapılabilecek yapı ve tesislere ilişkin hükümler oluşturmaktadır. Bu yasal düzenlemelerde zaman içinde yapılan değişikliklere bakıldığında, kıyı alanlarının yapılaşmasına olanak tanıdığı görülmektedir. I980'ler ve 1990'lardaki bu yasal düzenlemelerde BKAY ve planlaması ile ilgili herhangi bir kavramın, ilke ya da esasın yer almadığı, güncel kıyı alanları yönetimi konularından uzak, korumadan çok kullanmaya yönelik ve yalnızca kıyı alanlarındaki yapılaşma koşullarının ve süreçlerinin belirlendiği sektörel bir yaklaşımın egemen olduğu hükümlerden oluştuğu görülmektedir.

201 I yılında yürürlüğe giren 644 sayılı'2 ÇŞB'nin Teşkilat ve Görevleri Hakkında Kanun Hükmünde Kararname (KHK) ile kıyı alanlarında planlama ve uygulama ile ilgili görev ve yetkiler yeniden düzenlenmiştir. Bu KHK ile, "bütünleşik kıyı alanları yönetimi ve planlaması çalışmaları, kıyı alanlarının düzenlenmesine dair iş ve işlemler ile bu alanlara ilişkin jeolojik ve jeoteknik etütleri yapmak, yaptırmak ve onaylamak, kıyı kenar çizgisini tespit etmek, onaylamak ve tescilini sağlamak" ve "kıyı ve dolgu alanları ile bu alanların fonksiyonel ve fiziksel olarak devamı niteliğindeki geri sahalarına ilişkin her tür ve ölçekteki etüt, harita ve planları yapmak, yaptırmak ve resen onaylamak ve bunların uygulanmasını sağlamak” ÇŞB'nin görevleri arasında yer almıştır. ${ }^{13}$ Böylece, Türkiye'de BKAY kavramı ilk kez bir yasal düzenleme içinde yer bulmuştur.

8 T.C. Resmi Gazete. (1982). Turizmi Teşvik Kanunu. Kanun no: 2634, Kabul Tarih: I2/03/I982, Sayı: I7635 Tertip: 5 Cilt:2I Sayfa 262. Ankara, Madde 3,7.

9 T.C. Resmi Gazete. (1985). İmar Kanunu. Kanun no: 3194, Kabul Tarih: 09/05/1985, Sayı: I8749 Tertip: 5 Cilt:24 Sayfa 378. Ankara, Madde 2.

10 T.C. Resmi Gazete. (02/04/2013). Kıyı Kanununun Uygulanmasına Dair Yönetmelikte Değişiklik Yapılmasına Dair Yönetmelik. 28606.

"I T.C. Resmi Gazete. (17/04/1990). 362I Sayılı Kıyı Kanunu, 20495, I-4.

12644 sayılı KHK yürürlükten kaldırılmış ve Bakanlığın kuruluşu Cumhurbaşkanlığı I nolu Kararnamesi ile gerçekleşmiştir.

13 T.C. Resmi Gazete. (mükerrer) (04/06/20II). 644 Sayılı Çevre ve Şehircilik Bakanlığının Teşkilat ve Görevleri Hakkında Kanun Hükmünde Kararname, 27984. 
2014 yılında yürürlüğe giren ve 3194 sayılı İmar Kanunu ile 644 sayılı KHK'nin ilgili maddelerine dayanılarak hazırlanan Mekansal Planlar Yapım Yönetmeliği ise, kıyı alanlarında bütünleşik planlama ve uygulama açısından önemli hükümler içermektedir. Yönetmelikte, BKAY değil, bütünleşik kıyı alanları planı (BKAP) olarak tanımlama yapılmış ve planların hazırlanması sürecindeki esaslara yer verilmiştir. "BKAP, kıyıları, etkileşim alanı ile birlikte tüm sektörel faaliyet ve planlar ile sosyal ve ekonomik konuları da içerecek şekilde bütünleşik bir yaklaşımla ele alan; kıyı alanlarındaki fonksiyon ve faaliyetler ile kıyı alanlarına yönelik hedefler arasındaki uyumu sağlayan; sürdürülebilir gelişme ilkesi doğrultusunda kıyı ekosisteminin korunmasını ve doğal kaynakların kullanımını gözeten; ulaşım türleri ile ilgili kıyıda yapılması gerekli altyapı tesislerini içeren; koruma ve kullanma dengesini sağlayacak biçimde mekânsal hedef, strateji ve eylem önerilerini ve yönetim planını kapsayan, I:25 000 veya 1:50 000 ölçekte şematik ve grafik planlama diline uygun, plan paftası ve planlama raporu ile bütün olarak stratejik planlama yaklaşımı çerçevesinde ilgili kurum ve kuruluşlar ile işbirliği içinde hazırlanan plan" olarak tanımlanmıştır. ${ }^{14}$ Yönetmeliğin Mekansal Planlama kademeleri ve ilişkileri başlıklı 6. maddesinde ise; "BKAP mekansal planlama kademelenmesinde yer almayan, kıyı ve etkileşim alanına özgü stratejik yaklaşımla hazırlanan ve imar planlarını yönlendiren plan" olarak tanımlanmaktadır. ${ }^{15}$ Söz konusu Yönetmelik, bu zamana kadar bütünleşik kıyı alanları konusuna yer verilen en kapsamlı yasal düzenlemedir. Ancak, kavramın BKAY olarak değil de, BKAP olarak tanımlanması, konunun bir yönetim süreci değil, bir plan türü olarak değerlendirildiği sonucunu doğurmaktadır. BKAP'ın Stratejik planlama yaklaşımı çerçevesinde hazırlanması öngörülmekle birlikte, ölçeği ve planlama dili gibi özelliklerin tariflenmesi ile daha çok mekansal planlama ağırlıklı bir yaklaşım olarak değerlendirildiği söylenebilir.

BKAP'ın Türkiye'deki mekansal planlama hiyerarşisi ve düzeni içinde bir yerde konumlandırılmayan ve kıyı alanlarındaki planlama ve uygulamaları yönlendirici nitelikte bir plan olması nedeniyle hukuki yaptırımı ve bağlayıcılığı açısından bir eksikliğin de beraberinde geldiğini belirtmek olanaklıdır. Öte yandan, Mekansal Planlar Yapım Yönetmeliği'nde geçen kavram, tanım, ilke ve esaslar incelendiğinde; doğal kaynakların korunması, sürdürülebilir gelişme, sektörler ve faaliyetler arası uyumun ve eşgüdümün sağlanması, kamu yararı, katılımcı bir yönetim modelinin oluşturulması gibi BKAY'ın evrensel özellikleri ile örtüşen ilkelerin ilk kez dile getirildiği görülmektedir. Bu ilkelerin yasal düzenlemelerde yer bulması olumlu bir gelişmedir. Ancak bu ilkelerin gerçekleştirilebilmesi için yapılması gerekenler hakkında somut bir yaklaşıma yer verilmediği ve planların hazırlanması sürecinde ağırlıklı olarak kıyı yapıları üzerin-

14 T.C. Resmi Gazete. (14/06/2014). Mekansal Planlar Yapım Yönetmeliği, 29030.

15 T.C. Resmi Gazete. (14/06/2014). Mekansal Planlar Yapım Yönetmeliği, 29030. de durulduğu görülmektedir. Türkiye'de BKAY ve planlaması konusunda önemli bir yasal düzenleme konumunda olan bu Yönetmelik, bu alanda yaratılacak farkındalığa katkı sağlamakla birlikte, yalnızca planlama odaklı bir yaklaşım sunması açısından sakıncalar barındırmaktadır. Zaten karmaşık yapıda olan mevcut düzendeki planlama ve uygulamaya ilişkin işlemlerde belirsizliklere yol açması söz konusudur.

Türkiye'de, kıyı alanlarının yönetimi ve planlamasını doğrudan olduğu gibi, dolaylı olarak da ilgilendiren yasa, KHK, yönetmelik gibi çok sayıda yasal düzenleme bulunmaktadır. Bu yasal düzenlemelerin kıyı alanlarında etkinlik içinde bulunan sektörlerin kendi kuralların belirleme gereksinimi sonucunda kıyı alanlarının korunması, planlanması, işletilmesi ya da kullanılması amacıyla ortaya çıktığı görülmektedir.

\subsection{Kurumsal Düzenlemeler}

Türkiye'de kıyı alanları yönetimi ve planlaması ile ilgili kurumsal düzenlemeler yasal düzenlemelerde de olduğu gibi çok parçalı bir yapıdadır. Denizcilik, ulaşım, endüstri, enerji, güvenlik, turizm, doğa koruma, sit alanları, su ürünleri gibi alanlarda yer seçimi, planlama, uygulama, denetleme, yönetim planı, özelleştirme, arazi tahsisi, kiralama, inşaat izni, kullanma izni, irtifak hakkı, işletme gibi kıyı ile de ilgili olabilecek çeşitli konularda yasalar ile yetkilendirilmiş çok sayıda kurum ve kuruluş bulunmaktadır. 20I I yılında yeniden yapılandırılarak görev, yetki ve sorumlulukları belirlenen bu kurumlar arasında, birincil derecede yetkili ve sorumlu kurum ÇŞB'dir. Kıyı alanlarının planlanması ile ilgili görev, yetki ve sorumluluklar Mekansal Planlama Genel Müdürlüğü tarafından yürütülmektedir. Genel Müdürlük, 362I sayılı Kıyı Kanunu ile Uygulama Yönetmeliği kapsamında kıyı kenar çizgisinin deniz ve kara tarafındaki imar planlarına ilişkin iş ve işlemleri yürütmek ile bu planları onaylamak, kıyı alanlarının kara yönündeki arka alanı niteliğinde kalan alanlarda yürütülen imar planlama çalışmalar ile BKAP yapılması ve onaylanmasına ilişkin iş ve işlemleri yürütmekle görevlendirilmiştir. Ayrıca, Akdeniz'de BKAY Protokolü Ulusal Odak Noktası olma görevini de yürüten Genel Müdürlük tarafından Türkiye'nin Akdeniz'de BKAY Protokolüne taraf olmasının sağlanması, buna ilişkin orta ve uzun erimli eylem planının hazırlanması ve BKAY kapsamında yasal, idari ve hukuki kurumsallaşma ile kıyı alanları planlaması pratiğinin uygulamaya ivedilikle geçirilmesi amacıyla hazırlanan BKAY Strateji ve Eylem Planı Projesi 2013 yılında tamamlanmıştır.

Milli parklar, tabiat parkları, tabiat anıtları, tabiatı koruma alanları, doğal sit alanları, sulak alanlar, özel çevre koruma bölgeleri gibi alanların tespit, tescil, onay, değişiklik, ilan gibi iş ve işlemleri ise, Tabiat Varlıklarını Koruma Genel Müdürlüğü tarafından yürütülmektedir. Öte yandan, Çevre Yönetimi 
Genel Müdürlüğü ve Çevresel Etki Değerlendirmesi, İzin ve Denetim Genel Müdürlüğü tarafından deniz koruma ve kirliliğinin izlenmesi faaliyetleri ile kıyı alanlarında yapılacak yapı ve tesislere ilişkin çevre etki değerlendirmesi işlemleri yürütülmektedir. ÇŞB bünyesinde kurulan birimler incelendiğinde, mekansal planlama ve çevre faaliyetleri olarak ikiye ayrılmış sektörel nitelikli bir kurumsal yapılanma görülmektedir.

Türkiye'de henüz BKAY konusunda yatay ve dikey kurumsal bütünleşmeyi sağlayan bir organizasyona sahip olunmadığı görülmektedir. Bunun için kurumlar arası eşgüdümü sağlayacak öncü bir yapılanmaya gereksinim vardır. Her ne kadar verilen görevler itibariyle bu görevi ÇŞB üstlenmiş olsa da; uzmanlaşma, insan kaynağı, teknik donanım gibi eksikleri bulunmaktadır. Bu nedenle, konu özelinde doğrudan çalışmalar yapabilecek ya da bu çalışmaları yönlendirecek, bakanlık ya da bakanlıklar üstü düzeyde, tüm sektörler, üniversiteler, sivil toplum kuruluşları ve kurumlar arasında eşgüdümü sağlayabilecek, güçlü ve etkili bir merkezi kurum, kurul ya da kuruluşun yaşama geçirilmesi gerekmektedir. Öte yandan, yerel düzeyde de özellikle uygulama ile izleme ve denetleme faaliyetlerini yürütecek birimlere gereksinim duyulmaktadır.

Türkiye'de, ÇŞB'nin yanı sıra kıyı alanları yönetimi ve planlaması ile doğrudan ya da dolaylı olarak ilgili görev, yetki ve sorumlulukları olan diğer kurum ve kuruluşlar olarak Kültür ve Turizm Bakanlığı, Ulaştırma ve Altyapı Bakanlığı, Tarım ve Orman Bakanlığı, Hazine ve Maliye Bakanlığı, Genelkurmay Başkanlığı, belediyeler ve il özel idareleri sıralanabilmektedir. $\mathrm{Bu}$ kurum ve kuruluşlar arasında ÇŞB, BKAY ve planlaması açısından büyük önem taşımaktadır. Türkiye'nin henüz BKAY konusunda tüm bu kurum ve kuruluşlar ile ilişki kurabilen bir organizasyona sahip olmadığı görülmektedir.

\subsection{Planlama}

Türkiye'de kıyı alanlarında çok sayıda, farklı özellik ve ölçeklerde planlama çalışmaları yapılmaktadır. Bu çalışmaları, arazi kullanım ve yapılaşmaya yön veren mekânsal ve stratejik planlama çalışmaları olarak iki grupta ele almak olanaklıdır. Kıyı alanları ile ilgili olarak imar planları ve çevre düzeni planları mekansal planlama çalışmalarını, BKAY ve planlaması ise stratejik planlama çalışmalarını oluşturmaktadır. Bu çalışmaların yanı sıra, kıyı alanlarında çeşitli sektörlerin çalışmalarına yön veren tematik sektörel planlar ve strateji planları da bulunmaktadır. Deniz, göl ve akarsu kıyılarında planlama, uygulama ve denetim sürecine ilişkin planlama çalışmaları 362I sayılı Kıyı Kanunu ve Uygulamasına Dair Yönetmelik çerçevesinde yürütülmektedir. Bu kapsamda, kıyı alanları, doldurma yolu ile elde edilen dolgu alanları ve sahil şeritlerinde yapılması istenilen uygulamalar için imar planı yapılması zorunlu tutulmuştur. İlgili kurum ve kuruluşlar tarafından hazırlanan imar planı teklifleri, ÇŞB tarafından incelenmekte ve sonuçlandırılmaktadır. Kıyı Kanunu kapsamı dışında olan sahil şeridi gerisinde kalan alanlara ilişkin planlama süreci, 3194 sayılı İmar Kanunu çerçevesinde ilgili kurumlar tarafından yürütülmektedir. Bu nedenle, Kıуı Kanunu kapsamındaki alanlar ile kara tarafındaki devamı niteliğindeki alanlar birbirinden bağımsız ve kopuk bir biçimde planlanmaktadır. Çevre düzeni planlarında ise, kıyı alanlarına yönelik olarak yalnızca yasal düzenlemelere uyulması hususuna vurgu yapılmakta ve kıyı alanlarına ilişkin mevcut imar planları çevre düzeni planlarına işlenmektedir.

Türkiye'de kıyı alanlarında mekansal planlama çalışmaları, kurumsal ve yasal düzenlemelerdeki karmaşık ve parçalı yapının bir yansıması olarak ortaya çıkmaktadır. Kıyı Kanunu'na göre tanımlanan alanlarda planlama; belirli dar bir alanda ve yalnızca arazi kullanım kararları içeren, talebe yönelik bir biçimde, imar planları yolu ile alt ölçekli ve parçacı bir yaklaşım çerçevesinde gerçekleştirilmektedir. Bu nedenle, iki önemli sorun ortaya çıkmaktadır. Birincisi, Kıyı Kanunu kapsamındaki alanlar ile devamı niteliğindeki kara tarafına ilişkin alanlar, farklı yasalarla, farklı kurumlar tarafından, farklı planlar elde edilerek yapılmaktadır. İkincisi, çok uzun ve farklı özelliklerde kıyı yapılarına sahip olmasına karşın, üst ölçekli bölgesel stratejiler içeren bir yaklaşımın mekansal planlama sistemi içinde olmayışıdır. Tüm bu nedenlerden dolayı, birbiri ile işlevsel olarak ilişkili olmayan, çevreye uyumsuz kıyı yapı ve tesislerinin bir arada olduğu alanlar ortaya çıkmaktadır.

Türkiye'de kıyı alanlarının yeni bir yaklaşım ve model çerçevesinde planlanması ve bu alanların yalnızca kıyı ve sahil şeridinden oluşan bir alan değil, bir bölge olarak ele alınması ve bölge planlama anlayışı ile planlanması gerekliliğinden yola çıkılarak BKAY çalışmaları başlatılmıştır. Bu amaçla, kıyı alanlarının bütünleşik olarak üst ölçekten planlanmasına ilişkin projelerin hayata geçirilmesi için, 2007 yılında Bayındırlık ve İskan Bakanlığı tarafından İzmit Körfezi (Kocaeli-Yalova) ve İskenderun Körfezi (Adana-Mersin-Hatay) kıyı alanları pilot projeler olarak belirlenmiştir. Pilot çalışma olarak başlatılan bu projeler, Türkiye'de bir BKAY girişiminin ilk kez bir bakanlık tarafından yürütülmesi açısından oldukça önemli bir gelişme olmuştur.

201 I yılı, BKAY ve planlama çalışmalarının gelişimi açısından önemli bir yıl olmuştur. 2008 yılında onaylanan I: 50000 ölçekli İzmit Körfezi Bütünleşik Kıyı Alanları Planlama Projesi için şehircilik ilkelerine, planlama esaslarına ve kamu yararına uyarlık bulunmadığı sonucuna varıldığı öne sürülerek iptal kararı verilmesi istenilmiş ve 20 I I yılında Danıştay kararı ile iptal edilmiştir. ${ }^{16}$ Bilirkişi raporunda Planın genel yaklaşımı ve kapsamına ilişkin olarak; alt ölçekli planların bu plana uygun olarak ele alınması gerektiği ifadesinin belirsizlik yarattığı, kıyı ve kıyının geri kalan alanındaki kullanımlar ve farklı düzeylerdeki planlama çalışmaları arasında eşgüdümü sağlamaktan uzak ol-

${ }^{16}$ Danıştay 6. Dairesi'nin 29.06.20 I I tarihli ve E. 2009/886 ve K. 20 I I-2556 Sayılı Kararı. 
duğu ve bu nedenle bütünselliği sağlayamadığı, diğer planlama kararları ile çeliştiği gibi nedenler ortaya konulmuştur. ${ }^{17}$ Planın iptal olmasına neden olan gerekçeler incelendiğinde, Türkiye mekansal planlama hiyerarşisi içinde bir plan olarak değerlendirilmeye çalışıldığında diğer ölçeklerdeki planlar ile ilişkisinin ve planlama dilinin yeterince anlaşılamadığı görülmektedir. Aynı zamanda, iptal kararı ile birlikte bu planlama çalışmalarının güçlü bir yasal dayanağının ve yaptırım gücünün bulunmadığı da ortaya çıkmıştır. Dönem itibari ile BKAY ve planlaması ile ilgili herhangi bir yasal düzenlemenin bulunmaması, bunun en önemli nedeni olarak gösterilebilir.

Mekansal Planlar Yapım Yönetmeliği'nde belirtilen BKAP tanımı ile Türkiye'deki BKAY ve planlaması çalışmalarının bir planlama aracı olarak görüldüğü anlaşılmaktadır. Ancak mekansal plan dilinde ve hükmünde olmayan, yasal olarak güçlenmekle birlikte yaptırım açısından eksik bir plan türü olarak yürürlük kazanmıştır. Ayrıca, bundan sonra revize edilen önceki çalışmalar ve hazırlanan yeni çalışmalar bu tanım ile onaylanmaya başlanmıştır. Bu çalışmalar ile kıyı alanlarına ilişkin tüm planlama ve uygulamalara girdi sağlanması, kıyı kenar çizgisinin kıyı ve deniz tarafına ilişkin karar ve stratejiler üretilerek ilgili idareleri bağlayıcı, sahil şeridi ve kara tarafına ilişkin getirdiği stratejilerle de ilgili idarelerin uygulamalarına yol gösterici planlar elde edilmesi beklenmektedir. ${ }^{18} \mathrm{Bu}$ planlama çalışmaları sonucunda, halihazırda 1:25 000-1:50 000 arası ölçeklerde grafik gösterime sahip şemalar ve paftalar, açıklama raporları ve plan hükümleri ile bir yönetim modeli de ortaya konulmaktadır.

Bakanlık düzeyinde yaklaşık 10 yıldır yürütülen BKAY ve planlaması çalışmalarının tüm Türkiye kıyı alanları için tamamlanması hedeflenmektedir. Geçen bu süreçte, hem plan yapım aşamasında, hem de davaya konu olan planlardan edinilen deneyimlere ve dünyadaki gelişmelere bağı olarak yasal ve kurumsal birtakım gelişmelerin olduğu ve çalışmaların da bu doğrultuda gelişerek güncellendiği görülmektedir. Türkiye için yeni bir konu olan BKAY ve planlamasının zaman içinde başka değişiklikler de geçirmesi beklenmektedir. Bu nedenle, bu çalışmalardan etkili sonuçlar elde edilebilmesi için geleceğe ilişkin iyi kurgulanmış yol gösterici nitelikte bir belgeye gereksinim bulunmaktadır.

Türkiye'de kıyı alanlarının yönetimi ve planlanması ile ilgili yönetsel konulara çok sayıda belgede rastlamak olanaklıdır. Kalkınma planlarında, kıyı alanları yönetimi ve planlaması konusu çok ayrıntılı olarak yer almasa da, çevre, yerleşme ve kentleşme gibi başlıklar altında ele alındığı görülmektedir. Örneğin, VI. (1990-1994) Beş Yılık Kalkınma Planı, kıyı alanlarına yönelik doğrudan düzenlemeler getiren ilk kalkınma planı olarak göze çarpmaktadır. Çevre sorunları başlığı altında, kıyı şeridinin ya- rarlı ve ekonomik fayda elde edilmesinde kullanılması amacıyla öncelikli kamu yararını gözeten bir master plan hazırlanacağı belirtilmiştir (Uçlar, 20I2). Bu süreçte, 1992 yılında gerçekleştirilen Rio Konferansı'nın etkili olduğu görülmektedir.

IX. (2007-20I3) Kalkınma Planı'nda, stratejik mekansal planlama yaklaşımının da etkisiyle, kıyı alanları için ayrıca Bütünleşik Kıyı Alanları Yönetimi ve Deniz Kirliliğinin Önlenmesi başlıklı bir bölüme yer verilerek bütün kıyı alanları için uluslararası yükümlülükler dikkate alınarak bütünleşik yönetim planlarının hazırlanması ve uygulamaya geçirilmesi gerekliliği vurgulanmıştır (DPT, 2006). X. (20l4-20I8) Kalkınma Planı'nda ise, kıyı mevzuatının kıyı alanlarına yönelik konularda temel düzenleyici rolü olmakla birlikte kıyı alanlarının bütünleşik yönetimi ve planlanması açısından yeterli olmadığı ve kıyı alanları ile ilgili karar mekanizmalarının çok sayıda kurum ve kuruluşun yetkileri içinde sektörlere ve alanlara göre ayrışmış olmasının bütünleşik bir yönetim ve planlama yaklaşımını engellediği belirtilmiştir (Kalkınma Bakanlığı, 20I3). X. Kalkınma Planı ile diğer planlardan farklı olarak BKAY ve planlamasının, mekânsal planlama başlığı altında ele alındığı ve özellikle yönetsel konulara önem verildiği görülmektedir.

Uluslararası gelişmelerin yansımaları sonucunda özellikle 1990 sonrasında Türkiye'de de önemli yasal, kurumsal ve planlama ile ilişkili gelişmelerin yaşandığı görülmektedir. Ancak Türkiye'nin uluslararası gelişmelere uzak kalmamakla birlikte yeteri kadar da dahil olamadığı sonucuna varmak da olanaklıdır. Akdeniz ve Karadeniz Havzası'nın önemli bir ülkesi olarak Türkiye'nin, Akdeniz Eylem Planı, Karadeniz Çevre Programı ve Barselona Sözleşmesi gibi girişimlere dahil olduğu ve bu doğrultuda kurumsal ve yasal birtakım iç düzenlemelere gidildiği görülmektedir. Öte yandan, Akdeniz ülkeleri genelinde BKAY Protokolü gibi önemli belgelerin henüz benimsenmediği görülmektedir. Uygulamaya yönelik ise özellikle Akdeniz Havzası'nda yürütülen pilot çalışmalar arasında Türkiye'den de alanlar seçildiği görülmektedir. Özgün yapılarından dolayı ülkeler arasında karşılaştırma yapmak güç olmaktadır. Ancak Avrupa Birliği üyesi ülkelerin, üye olmanın getirdiği birtakım yükümlülüklerin yerine getirilmesi ve sahip oldukları katılım kültürü gibi nedenlerden Türkiye'den daha gelişkin BKAY ve planlaması çalışmaları olduğunu söylemek olanaklıdır. BKAY ve planlamasının evrensel normları çerçevesinde Türkiye'nin sorunlarının ve eksikliklerinin tespit edilmesi ve bu doğrultuda gerekli somut adımların atılması bir gereklilik olarak ortaya çıkmaktadır.

\section{Yöntem}

Ekolojik değerlerin korunması ile ekonomik çıkarların yarattığı baskının oluşturduğu çatışmayı, sürdürülebilirlik ilkesi

\footnotetext{
17 Danıştay 6. Dairesi'nin 29.06.20II tarihli ve E. 2009/886 ve K. 20I I-2556 Sayılı Kararı.

${ }^{18}$ Bütünleşik Kıyı Alanları Planlaması Çalışmaları. Çevre ve Şehircilik Bakanlığı Mekansal Planlama Genel Müdürlüğü. URL: http://www.webcitation.org/ query?url=https\%3A\%2F\%2Fwww.csb.gov.tr\%2Fgm\%2F mpgm\%2Findex.php\%3FSayfa\%3Dsayfa\%26Tur\%3Dwebmenu\%26Id\%3DII625\&date=20I7-04-I I (erişim tarihi: II/04/2017).
} 
doğrultusunda dengeleyebilecek ve akılcı bir yöntem ile ele alabilecek yönetsel ölçütlerin geliştirilerek gelecekte daha etkin ve başarılı bir BKAY'ın ortaya konulması, sürecin ilk ve en önemli adımı olarak değerlendirilmelidir. Bu çalışmada bu ölçütlere temel oluşturacak ulaşılması beklenen amaç ve hedefler belirlenip, bu amaç ve hedefler üzerinden mevcut durumun değerlendirilmesi ve önerilerin geliştirilmesi yoluna gidilmiştir. Türkiye'de ulaşılması beklenen bu amaç ve hedefler, bu hedeflerin varlığı, etkinliği, yeterliliği ve işlevselliği gibi açılardan değerlendirilebilecek nitelikler taşımaktadır. Bu nedenle, BKAY sürecinin yönetsel boyutu, yapısı gereği nitel araştırmaya daha uygun bir alan olarak değerlendirilmiş ve "olgu ve olaylar ile aralarındaki karmaşık ilişkinin kendi bağlamı içinde yorumlanmasına" olanak veren nitel araştırma tekniklerine başvurulmuştur (Özkalp, 2016). Bu doğrultuda ilk olarak nitel veriler çerçevesinde amaç ve hedefler belirlenmiş; bu amaç ve hedefler referans alınarak mevcut duruma ilişkin bir değerlendirme yapılması ve bu değerlendirmenin de göz önünde bulundurularak Türkiye'ye özgü öneriler geliştirilmesi yöntemi tanımlanmıştır. Bu yöntemin gerçekleşebilmesi için ise, yorum ve görüşlere gereksinim duyulmuş ve bu nedenle derinlemesine görüşme yöntemi seçilmiştir. Bu doğrultuda uzmanları yönlendirecek bilgilerin ve uzmanlara yöneltilecek belirli başlıklar altında soruların yer aldığı bir görüşme föyü hazırlanmış ve BKAY konusunda çalışmalarda bulunmuş ya da bulunan uzman niteliğinde olabilecek kişilerle görüşmeler yapılmıştır. BKAY ile ilişkili önemli başııklar siyasal, yasal, kurumsal düzenlemeler ile birlikte BKAY planları ve uygulamaları, katılım, bilgi/farkındalık/eğitim ve araştırma ile izleme/değerlendirme olarak belirlenmiştir.

Bu başlıklar altında görüşme yapılan uzmanlara, Türkiye için belirlenen amaç ve hedefler sunulmuş, mevcut durum hakkında bilgilendirme yapılmış, mevcut durumun sorun ve eksiklikleri ile bu sorun ve eksikliklerin giderilmesine yönelik yapılması gerekenler ile ilgili olarak önerilerin geliştirilmesine yönelik sorular yöneltilmiştir. Bu başlıklar, çalışmada BKAY ile ilgili olarak dünya üzerinde bugüne kadar yapılan kuramsal ve uygulamaya yönelik çalışmalardan elde edilen sonuçların ortak özelliklerinden yararlanılarak ortaya konulmuştur.

Çalışmanın hedefi ile paralel olarak BKAY ile ilişkili yasal, kurumsal ve planlama ile ilgili olduğu konuların yeterli olup olmadıklarını belirlemek üzere 24 uzman ile derinlemesine görüşme yapılmıştır. Görüşme yapılan uzmanların seçiminde ise, BKAY konusunda kuramsal ya da uygulamaya yönelik çaIışmalar yürütmüş ya da bu çalışmaların içinde yer almış kişilerden iletişim kurulabilecek kişiler tespit edilmiştir. BKAY'ın yönetim boyutunu inceleyen çalışma konusu çok sayıda çalışma alanını ve disiplinini ilgilendirdiği için tespit edilen kişilerin olabildiğince farklı sektör ve dallardan, farklı kuruluşlardan ve farklı uzmanlık alanlarından dengeli bir biçimde seçilmesine özen gösterilmiştir. Bu amaçla, üniversite ve enstitülerin deniz bilimleri, kıyı mühendisliği, çevre bilimleri, su ürünleri, ziraat, kamu yönetimi ve şehir ve bölge planlama bölümlerinden; bakanlıklar ve yerel yönetimlerden; kıyı ve deniz ile ilgili koruma ve araştırma etkinlikleri yürüten dernek ve vakıflardan; Birleşmiş Milletler Kalkınma Programı (UNDP) ve Doğal Hayatı Koruma Vakfı (WWF) gibi uluslararası kuruluşlardan uzmanlar ile iletişime geçilmiştir. Bunun yanı sıra Deniz Ticaret Odası ve kalkınma ajansı gibi kuruluşlarla da bağlantı kurulmuştur. Görüşme için seçilen bu kişiler, akademik çevre, kamu kuruluşları, planlama büroları, sivil toplum kuruluşları ve uluslararası kuruluşlar olmak üzere beş grupta sınıflandırılmıştır. Meslek odaları sivil toplum kuruluşları grubunda, kalkınma ajansı ise kamu kuruluşları grubunda değerlendirilmiştir.

Uzmanlardan öncelikle genel başlıklar altında mevcut durumu değerlendirmeleri istenmiş ve likert ölçeği kullanılarak bir yeterlilik sıralaması elde edilmiştir. Mevcut durum değerlendirmesinde yanıtlar, yanıt yok, yeterli değil, kısmen yeterli ve yeterli olarak sınıflanmış ve likert ölçeği indeksi ile ağırlıklarına göre sıralanmıştır. Likert ölçeği indeksi, yanıtlar için oluşturulan seçeneklerdeki kişi sayılarının cevaplara göre sırasıyla $0,1,2$, 3 değerleri ile çarpılarak toplanan sonucun toplam görüşülen kişi sayısına bölünmesi ile hesaplanan bir sıralama indeksidir.

Daha sonra da Tablo I'de de sıralanan 24 adet açık uçlu soru yardımıyla yanıtların ortak baskın özellikleri ile özgün yönlerinin öne çıkarılması sağlanmıştır. Bu değerlendirme sonuçları göz önünde bulundurularak geleceğe yönelik önerilerin belirlenmesi amacıyla oydaşma sağlanan konular ile farklı bakış açılarının bulunduğu konuların neler olduğu saptanmaya çalışılmıştır.

\section{Araştırma Bulguları}

Likert ölçeği ile yapılan sıralamaya göre yasal düzenlemelerin göreli olarak diğer başlıklardakilerden daha yeterli olduğu sonucuna varılmıştır (Tablo 2). Bu başlı̆̆ı BKAY Planları ile siyasal düzenlemelerin yeterlilikleri izlemektedir. Kurumsal düzenlemeler, bilgi/farkındalık/eğitim ve araştırma ile izleme/değerlendirme ile katılım başlıkları için hiçbir uzmanın yeterli olduğu yönünde yanıt vermediği ve likert ölçeği indeksinin de diğer üç boyuttan daha düşük olduğu belirlenmiştir. Türkiye'de BKAY ve planlamasının yönetsel açıdan yeterliliğinin genel anlamda çok düşük düzeyde olduğunun düşünüldüğü gözlemlenmektedir.

Sonraki bölümlerde görüşmelerde açık uçlu sonuçlara verilen yanıtlar kapsamında mevcut durum değerlendirmesinin detayları verilmektedir.

\section{I. Siyasal Düzenlemeler}

BKAY ve planlaması ile ilgili siyasal düzenlemeler başlığı altındaki en önemli eksikliğin belirli bir kıyı politikası ve vizyonunun olmayışı olarak görülmektedir. Hangi politik çerçeve içinde, hangi aktörlerin söz sahibi olacağı belirsiz durumdadır. Diğer 
Tablo I. Belirlenen başlıklar kapsamındaki sorular

\begin{tabular}{|c|c|}
\hline Başlıklar & Sorular \\
\hline \multirow[t]{5}{*}{ Siyasal düzenlemeler } & I. BKAY ve Planlamasında ne tür bir yaklaşım ve vizyon benimsenmeli? \\
\hline & 2. Hangi ilke ve stratejiler ele alınmalı? \\
\hline & 3. BKAY hangi yönetsel düzeyde (ulusal, bölgesel, yerel) ele alınmalı? \\
\hline & 4. BKAY hangi düzeydeki aktörler tarafından düzenlenmeli? \\
\hline & 5. BKAY ile ilgili hangi düzenlemeler kısa, hangi düzenlemeler uzun erimde ele alınmalı? \\
\hline \multirow[t]{6}{*}{ Yasal düzenlemeler } & 6. Nasıl bir yasal düzenlemeye gidilmeli? \\
\hline & (Mevcut yasaların revize edilmesi veya BKAY özelinde yasal düzenleme oluşturulması gibi) \\
\hline & 7. Eğer BKAY için bir yasal düzenleme yapılması gerekiyorsa içeriği nasıl olmalı? \\
\hline & 8. İzinli ve yasaklı faaliyetler ile aktörlerin yetki alanları nasıl ve neye göre tanımlanmalı? \\
\hline & 9. Hangi amaç, kapsam, içerik ile sınırlar çerçevesinde hazırlanmalı? \\
\hline & I0. Uluslararası boyuttaki belgeler ile yasal düzenlemelere bir katkı sağlanabilir mi? \\
\hline \multirow[t]{3}{*}{ Kurumsal düzenlemeler } & II. Ne tür yöntem ve mekanizmalar izlenmeli? \\
\hline & 12. Hangi yönetsel düzeyde (ulusal, bölgesel, yerel) bir koordinasyon organı/organizasyon kurgulanmalı? \\
\hline & 13. Hangi aktörlere, (merkezi, yerel, sivil toplum kuruluşları vb.) ne tür yetkiler verilmeli? \\
\hline \multirow[t]{4}{*}{ BKAY planları ve uygulamaları } & I4. Alana özgü yaklaşım, eylem ve stratejiler nasıl belirlenmeli? \\
\hline & I5. Statüsü, yaptırım gücü, özellikleri ve içeriği nasıl olmalı? \\
\hline & 16. Coğrafi sınırları, planlama dili (mekansal, stratejik vb.) ve ölçeği ne olmalı? \\
\hline & $\begin{array}{l}\text { I7. Planlama çalışmaları, hangi aktörler tarafından, (merkezi, yerel vb.) hangi yönetsel düzeyde (ulusal, } \\
\text { bölgesel, yerel) ve hangi erimde (kısa, orta, uzun) yürütülmeli? }\end{array}$ \\
\hline \multirow[t]{3}{*}{ Katılım } & I8. Katılımın en yüksek düzeyde, en etkili bir biçimde sağlanabilmesi ve sivil toplum kuruluşlarının daha \\
\hline & aktif olabilmesi için ne tür yöntemler izlenmeli? \\
\hline & $\begin{array}{l}\text { 19. Hangi düzeyde, (ulusal, bölgesel, yerel) hangi aktörler (merkezi, yerel, sivil toplum kuruluşlarının, } \\
\text { üniversiteler vb.) tarafından nasıl bir organizasyon/mekanizma tariflenmeli? }\end{array}$ \\
\hline \multirow[t]{2}{*}{$\begin{array}{l}\text { Bilgi, farkındalık, } \\
\text { eğitim ve araştırma }\end{array}$} & $\begin{array}{l}\text { 20. Bilgi ve farkındalığın arttırılması için hangi düzeyde (ulusal, bölgesel, yerel) hangi aktörler (merkezi, } \\
\text { yerel, sivil toplum kuruluşları, üniversiteler vb.) tarafından ne tür etkinlikler yapılmalı? (yayınlar, medya, } \\
\text { eğitim programları vb.) }\end{array}$ \\
\hline & $\begin{array}{l}\text { 2I. BKAY ile ilgili bilimsel araştırmaların arttırılması ve bu alanda uzmanlaşmanın sağlanması için nasıl bir } \\
\text { yol izlenmeli ve ne tür düzenlemelere (yasal, kurumsal, akademik vb.) gidilmeli? }\end{array}$ \\
\hline \multirow[t]{4}{*}{ İzleme ve değerlendirme } & 22. Etkin bir izleme ve değerlendirme sistemi kurulabilmesi için hangi uygulama araçları kullanılmalı ve nasıl \\
\hline & bir yöntem ya da yönetim modeli benimsenmeli? \\
\hline & $\begin{array}{l}\text { 23. Hangi yönetsel düzeyde (ulusal, bölgesel, yerel) nasıl bir organizasyon kurgulanmalı? (danışma birimleri, } \\
\text { izleme birimleri vb.) }\end{array}$ \\
\hline & 24. Hangi aktörler (merkezi, yerel vb.) hangi erimde (kısa, orta, uzun) ne tür görevler üstlenmeli? \\
\hline
\end{tabular}

Tablo 2. Mevcut durumun yeterliliğinin likert ölçeği ile karşılaştırılması

\begin{tabular}{lccccc}
\hline Başııklar & Yanıt yok (\%) & Yeterli değil (\%) & Kısmen yeterli (\%) & Yeterli (\%) & Likert indeksi \\
\hline Yasal düzenlemeler & 45,8 & 29,2 & 16,7 & 8,3 & 0,88 \\
BKAY planları & 50,0 & 29,2 & 16,7 & 4,2 & 0,75 \\
Siyasal düzenlemeler & 41,6 & 50,0 & 4,2 & 4,2 & 0,71 \\
Kurumsal düzenlemeler & 33,3 & 62,5 & 4,2 & 0,0 & 0,71 \\
Katılım & 41,6 & 50,0 & 8,3 & 0,0 & 0,67 \\
Bilgi, farkındalık, eğitim ve araştırma & 45,8 & 45,8 & 8,3 & 0,0 & 0,63 \\
İzleme ve değerlendirme & 58,3 & 37,5 & 4,2 & 0,0 & 0,45 \\
\hline
\end{tabular}


önemli eksiklik ve sorunların başında ise; belirli bir eşgüdüm mekanizmasının olmaması, uygulama aşamalarının hayata geçirilememesi, ilgili aktörler arasında yetki karmaşası olması, bilgi ve uzmanlaşma eksikliği olması ile yeterli düzeyde katılım olmaması gibi hususlar gelmektedir. Bu nedenle öncelikle izlenecek yolun kapsamlı ve açık bir biçimde ortaya konulması gerekmektedir. Bu kapsamda görüşmelerden elde edilen bilgilere göre yapılması gerekenler şu şekildedir:

- Illgili kesimlerden uzman kişiler ve tüzel kişiler bir araya getirilerek kıyı politikası için uzun erimli ülke vizyonu belirlenmelidir. Bu vizyon çerçevesinde ulaşılması gereken hedefler ile bu hedeflerin değerlendirilmesini sağlayacak ölçütler belirlenmelidir.

- Çevre duyarlı ve sürdürülebilir bir yaklaşım ile birlikte katılımcı bir kıyı yönetim modelinin hayata geçirilmesi benimsenmelidir.

- Ulusal düzeyde yürütülecek çalışmalara ilişkin aşamalar ve bu aşamalardan sorumlu aktörlerin işlevleri açıcça tanımlanmalıdır.

- Akdeniz'de BKAY Protokolü gibi uluslararası belgeler doğrultusunda ulusal ilke ve stratejiler belirlenmeli ve bu stratejilerin kalkınma planları, master planlar, strateji belgeleri, eylem planları gibi sektörlere yön veren belgelere yansıtılması sağlanmalıdır.

- Oluşturulacak strateji belgesinin yanı sıra tüm kıyı alanlarının profilleri çıkarılmalı ve alt bölgeler oluşturularak teknik analizleri içeren bir envanter çalışması yapılmalıdır. Bu envanter çalışmasında, kıyı alt bölgelerinin ekolojik, çevresel, fiziksel, oşinografik vb. açıdan özellikleri belirlenmelidir.

\subsection{Yasal Düzenlemeler}

BKAY ve planlamasının etkinliğinin sağlanabilmesinin ön koşutu olan yasal düzenlemeler konusunda Türkiye'de bir birikime sahip olunulduğu görülmekle birlikte, bu yasal düzenlemelerin nitelik açısından eksikliklerinin olduğu söylenebilir. Kıyı alanları ile ilgili çok sayıda yasal düzenlemenin olması, bu düzenlemelerin çelişkiler barındırması; BKAY, kıyı ve ilgili tanımların belirsizliği; kıyıların korunması ile ilişkili düzenlemelerin olmaması mevcut düzenlemelerin eksiklikleri olarak saptanmıştır.

Yapılan derinlemesine görüşmelerden elde edilen bilgiler ışığında yapılması gerekenler aşağıda sıralanmaktadır:

- Akdeniz'de BKAY Protokolü başta olmak üzere uluslararası belgeler ve ilkeler doğrultusunda, BKAY ve planlamasında izlenecek stratejilerin, amaç ve hedeflerin, kurumsal düzenlemelerin, sınırılıkların, izinli ve yasaklı faaliyetlerin, izleme ve değerlendirme faaliyetleri ile katılım sürecinin genel hatlarıyla belirlendiği bir yasa hazırlanmalıdır.

- Bu yasa, kıyı alanlarını kara ve su tarafı ile birlikte ele alan ve çevresel değerleri göz önünde bulunduran bir yaklaşım ile hazırlanmalıdır.

- Kıyı bölgeleri ve koruma statüleri açıkça tanımlanmalıdır.
- Bu doğrultuda ikincil yasal düzenlemeler yapılabilir ve ilgili diğer yasalarda değişiklikler yapılarak bu çerçeve yasanın işlerliğinin artması sağlanabilir.

- Kıуı alanlarını ilgilendiren plan, proje, strateji belgesi, master plan, eylem planı gibi tüm çalışmaların ilgili kurumların kuruluş kanunları ile değil, bu çerçeve yasa ile hazırlanması sağlanmalıdır.

\subsection{Kurumsal Düzenlemeler}

Bu başlık altında yerine getirilmesi gereken önemli husus kurumlar arasında eşgüdüm sağlanmasıdır. Bunun sağlanması için de yeni kurumsal düzenlemelere gereksinim olduğu açıktır. Türkiye'deki, kıyı alanları yönetimi ve planlaması ile ilgili kurumsal düzenlemeler çok parçalı bir yapıya sahiptir. Bu konudaki en belirgin sorunların başında da, kurumlar arası yatay ve dikey eşgüdümü sağlayacak somut bir yapının olmaması ile kurum ve kuruluşlar arasında yetki karmaşasının yaşanması gelmektedir. Özel sektör temsilcileri, sivil toplum kuruluşları ve diğer paydaşlar arasında da eşgüdümü sağlayacak organizasyonlara gereksinim vardır. Bu kapsamda görüşmelerden elde edilen öneriler aşağıdaki gibidir:

- Öncelikle dikey ve yatayda eşgüdümü sağlayacak merkezi bir kuruluş belirlenmelidir. Bu kuruluş ulusal ve yerel düzeydeki tüm aktörleri bir araya getirebilecek nitelikte olmalıdır.

- Bu kuruluş, ÇŞB gibi bakanlık düzeyinde mevcut yapı içinde bir kuruluş olabileceği gibi bakanlıklar üstü ya da bakanlıklar arası bir kurul, konsey, ajans gibi bir yapı da olabilir. Ancak mevcut düzende bu durum oldukça güçtür. Bu nedenle en etkili yapının kurumlar arası bir kurul olacağı öngörülebilir.

- Bu kurulun kamu kurum ve kuruluşları tarafından belirlenecek temsilcilerin yanı sıra sivil toplum ve meslek kuruluşları ile üniversitelerden de temsilcilere sahip olması sağlanmalıdır. Bu yapının, daha çok karar alma konusunda danışma görevi yapması, sekretaryasının ise ÇŞB tarafından yapılması uygun gözükmektedir.

- Aynı şekilde merkez ile doğrudan temas halinde olabilecek yerel birimler de tanımlanmalıdır. Bu birimler valilikler ve belediyeler içinde kurulabilir. Bu birimlerin daha çok proje bazında işlemleri yürütecek, izleme ve değerlendirme çaışmalarını yerinde yapabilecek eylem odaklı bir nitelikte olması sağlanmalıdır.

\subsection{BKAY Planları ve Uygulamaları}

Türkiye'de BKAY süreci ile ilgili üzerinde en çok durulan ve birikim oluşmuş olan konunun planlama olduğu görülmektedir. Özellikle son on yılda planların hazırlanması aşamasında yoğun çaba gösterilse de, bu planların uygulanmasında sorunlar yaşanmaktadır. Bunun en önemli nedeni de, planların rehber niteliğinde ve yaptırım gücüne sahip olmayan nitelikte olmasıdır. Ayrıca, planların alt ölçeklerde belirsizlikler yaratması, uy- 
gulamanın yeteri düzeyde gerçekleştirilememesi, çok merkezi, üst ölçekli ve büyük alanları kapsayacak biçimde hazırlanması ve çevresel değerleri koruma açısından yeterli olmaması gibi nedenler de planların uygulanmasında sorunlara sebep olmaktadır. Bu kapsamda görüşmeler ışı̆̆ında aşağıdakiler önerilmektedir:

- Öncelikle BKAP yaptırımına ilişkin yasal ve kurumsal düzenlemeler yapılmalıdır.

- Kıyı alanlarında uyulması gereken stratejileri belirleyen bu planlara aykııı işlemlerin yapılmasının önüne geçilmesi için sorumlu tüm yetkili kurum ve kuruluşlar için bilgilendirme ve bilinçlendirme çalışmaları yapılmalıdır.

- Planlar hazırlanırken yalnızca kıyı yapılarının yapılmasını düzenleyen mekansal planlamaya değil, biyolojik çeşitlilik ve ekosistem açısından da kararlar getiren strateji ve eylemlere de öncelik veren yönetim planlamasına da önem verilmelidir.

- Çok genel strateji ve eylemlerin yer aldığı ve plan sınırlarının çok büyük alanları kapsadığı görülen bu çalışmaların alt bölge bazında daha ayrıntılı plan ve projeleri de ortaya konulmalıdır. Böylece genel kararlar üst ölçekte, yere özgü kararlar alt bölge ölçeğinde belirlenmelidir. Bu kapsamda yerel yönetimler ya da ilgili idareler tarafından bulunduğu bölge için bütünleşik imar planı çalışmaları yürütülebilir.

- Ölçek konusu planlama sınırına ve yere özgü koşullara göre esnek tutulmalıdır.

- Planlama çalışmaları merkezi düzeyde yürütülmeli, ancak uygulama konusunda yerelde yetkili kılınacak birimler sorumlu tutulmalıdır.

- Plan kapsamında öneri niteliğinde kararlar değil, uyulması zorunlu kurallar belirlenmelidir.

- Planlama dili şematik olmalı, ancak simgesel gösterimlerin yanı sıra koruma bölgeleri, hassas alanlar, özel bölgeler daha açık gösterilmelidir.

\subsection{Katılım}

BKAY sürecinin etkin olabilmesi için farklı aktörlerin katılımının sağlanması çok önemlidir. Görüşmelere göre, Türkiye'de katılımın yeterli düzeyde olmadığı sonucu ortaya çıkmaktadır. Bunun nedenleri olarak ise; genel olarak yönetim süreçlerine katılım düzeyinin düşük olması, ilgili aktörlerin yeteri kadar bilgilendirilmemesi, katılımı sağlayacak organizasyonların eksikliği ve katılımın yalnızca bilgilendirme ve görüş alma düzeyinde kalması görülmektedir. Bu kapsamda görüşmelerden elde edilenler aşağıdaki gibidir:

- Karar alma süreçlerinde saydamlık sağlanmalı, bu süreçlerin yalnızca bilgilendirme ve görüş alma düzeyinde değil aktif katılıma olanak verecek düzeyde olması sağlanmalıdır.

- Katılım süreçleri yasal düzenlemeler ile de desteklenerek tanımlanmalı ve bu süreçte paydaşlara ne tür görev ve yetkilerin dağıtılması gerektiği belirlenmelidir.
- Katılımın genel olarak yerelde çözülmesi gereken bir konu olduğu ve bu konuda öncü organizasyonların sivil toplum kuruluşları olmasından yola çıkılarak bu kuruluşlar ile kamu kuruluşları ve üniversitelerin işbirliği içinde yerel düzeyde örgütlenmelerin oluşturulmasına olanak verilmelidir. Kent Konseyi ve Yerel Gündem 21 gibi oluşumlar ile sürekli ve etkin bir kurumsal yapı elde edilebilir.

- Sivil toplum kuruluşlarının izleme ve denetim konularında sınırlı da olsa yetkileri olmalıdır ve planlama süreçlerine katılımı sağlanmalıdır.

- Doğrudan katılımın yanı sıra bilgi teknolojileri, dijital ortam, sosyal medya ve anketler yoluyla da özellikle toplumun katılımının sağlanabileceği uygulamalar yaşama geçirilmelidir.

\subsection{Bilgi, Farkındalık, Eğitim ve Araştırma}

Görüşmeler ışığında BKAY ve planlaması ile ilgili tüm konuların Türkiye'de yeteri kadar gündeme getirilmediği ve önemsenmediği sonucuna ulaşmak mümkündür. En önemli sorun ise, uzmanlar da dahil olmak üzere farkındalık düzeyinin yeterli olmamasıdır. Diğer önemli sorunları ise; ilgili kesimler ile toplumda yeterli bilgi/bilinç/farkındalık düzeyinin olmaması, bilimsel araştırmaların ve araştırma olanaklarının kısıtlı olması, konuya yeterli önemin ve ilgilinin verilmemesi, sivil toplum kuruluşlarının yeteri kadar aktif olamaması olarak sıralamak olanaklıdır. Bu nedenle atılacak ilk adımın bilgilendirme ve bilinçlendirmeye yönelik çalışmalar olması gerekmektedir. Bu kapsamda görüşmelerden elde edilen bulgular aşağıdadır:

- Öncelikle kamu kurumları, üniversiteler ve sivil toplum kuruluşları arasındaki iletişim eksikliği giderilmeli ve konunun önemine vurgu yapılmalıdır.

- Planlama çalışmaları sırasında yerel düzeyde yapılacak toplantıların ve bilgilendirme etkinliklerinin kapsamı genişletilmeli ve toplumun farkındalığııın arttırılması sağlanmalıdır.

- ÇŞB ve sivil toplum kuruluşları arasında işbirliği yapılarak düzenli aralıklarla eğitimler ve etkinlikler düzenlenmelidir. Örneğin bu konuda Akdeniz Kıyı Vakfı gibi sivil kuruluşlara destek verilerek konferans ve çalıştay gibi etkinliklerin düzenlenmesi vb. uygulamaların yaşama geçirilmesi sağlanabilir.

- Kıyı alanlarında yürütülen çalışmalar ile ilgili düzenli yayınlar, raporlar ve programlar sunulmalıdır.

- Kıyı günü gibi etkinlikler yeniden canlandırılmalı ve farkındalık oluşturmaya yönelik belirli bölgelerin özelliklerinin dikkatinin çekileceği kampanyalar yürütülmelidir.

- TÜBITAK gibi bilimsel kuruluşlar ile ÇŞB başta olmak üzere konuyla ilgili kurumlar tarafından bilimsel araştırmalara destek verilmelidir.

- Özellikle kıyı alanlarında yaşayan gençler başta olmak üzere eğitici tanıtım program ve projeleri yürütülmelidir.

- Bilimsel kuruluşlar, sivil toplum kuruluşları ve basın kuruluşları arasında işbirliği kurularak ortak projeler yürütül- 
melidir.

- Yerelde faaliyet gösteren sivil toplum kuruluşları yetkilendirilerek bilinçlendirme çalışmalarının yapılması sağlanmalıdır.

- Akademik çevrenin konuya ilgisini arttıracak teşvikler verilmeli, lisansüstü düzeyde BKAY programları başlatılmalıdır.

- Kamu spotları, sosyal medya ve özel internet sayfaları aracılığı ile daha çok kişiye daha etkin bir biçimde ulaşılması sağlanmalıdır.

\section{7. İzleme ve Değerlendirme}

İzleme ve değerlendirme, araştırma sonuçlarında da belirtildiği üzere BKAY ve planlaması konusundaki en yetersiz düzeyde olan konudur. Başka bir anlatımla, izleme ve değerlendirmeye ilişkin yöntem ve mekanizmaların bulunmadığını söylemek olanaklıdır. İzleme ve değerlendirme çalışmalarını yürütecek merkezi ve yerel birimlerin, yeterli verilerin ve belirlenmiş hedef/gösterge/referansların olmaması gibi hususlar bu alandaki önemli eksikliklerdir. Bu eksikliklerin giderilmesi için ise, izleme ve değerlendirme çalışmalarının yasal düzenlemelerle belirlenmesi ve yönetsel birimlerin kurulması gerekliliğidir. Bu kapsamda görüşmelerden elde edilenler aşağıdaki gibidir:

- Gerekli tüm verilerin elde edilmesi için girişimler başlatılmalı ve bu verilerin toplanacağı ve değerlendirileceği merkezi bir veri bankası oluşturulmalıdır. Bu konuda ÇŞB öncü kuruluş olabilir.

- Ulusal düzeyde ortak izleme sistemleri kurulmalı ve sürekli bilgi akışı sağlanmalıdır.

- Konusuna göre bölgesel ve yerel düzeyde saydam ve işlevsel izleme birimleri, ofisler ve yerel istasyonlar kurulmalıdır.

- İzleme ve değerlendirme yapılabilmesi için belirli aralıklarla veriler toplanarak kıyı alanlarındaki faaliyetler izlenmelidir.

- İzleme ve değerlendirmenin ölçülmesini sağlayacak plan özelinde hedef, gösterge ve referanslar belirlenerek çalışmaların etkinliği ve başarı düzeyi takip edilmeli, geri besleme yapılmalıdır.

- Takibin yapılabilmesine olanak veren coğrafi bilgi sistemleri ve uzaktan algılama gibi teknolojiler kullanılmalıdır.

- Ortaya çıkan sonuçların raporlanarak belirli aralıklarla kamuoyu ile paylaşılması sağlanmalıdır.

Mevcut duruma ilişkin olarak aktarılan temel eksiklikler ve sorunlar incelendiğinde, BKAY ve planlaması sürecinin stratejik mekansal planlamanın da karşı karşıya kaldığı yetersizlikler ve kısıtlılıklarla karşı karşıya kaldığı görülmektedir. Görüşme sonuçlarına göre Türkiye'de BKAY ve planlaması ile ilgili olarak ortak vizyon oluşturamama, kurumlar arası eşgüdümün yetersiz olması ve yetki karmaşası, yasal altyapı yetersizlikleri, hukuki yaptırım eksikliği ile alansal olarak parçalı kıyı yapısı bu alanların korunmasında ve etkin bir şekilde planlanmasında sorun yaratmaktadır.

\section{Sonuç}

Stratejik mekansal planlama 1990'lı yıllarda önem kazanarak yeni bir kurumsal ve siyasal düzen önerebiliyor olması, esnek yapısı, eylem odaklı, katılımcı ve müzakereci çözümlemeler sunması nedeniyle birçok ülkede farklı ölçeklerde mekansal planlamayı yönlendirmiştir. Ancak, son yıllarda, stratejik mekansal planlama yapısal olarak sahip olduğu kısıtlılıklar nedeniyle, diğer bir deyişle plan hiyerarşisinde yer almaması, hukuki yaptırımı ve bağlayıcılığının kalmaması, uygulama ile ilişkisinin kaybolması, çok aktörlü ve çok ölçekli özelliği nedeniyle planlama süreçlerine dahil olan aktörler arasında yetki karmaşasına neden olması sebebiyle zamanla önemini yitirmiştir. Ayrıca, son yıllarda planlamanın merkezileşmesi, katılımcı bir yaklaşım benimsenmemesi gibi faktörler de bu durumu olumsuz şekilde etkilemiştir.

Bir stratejik mekansal planlama ve yönetim şekli olarak BKAY ve planlanmasının da Türkiye'deki kıyı alanları için etkili olabilecek bir yönetim ve planlama şekli için potansiyel bir kapasite sunduğu söylenebilir. Ancak, uygulamada genel olarak BKAY ve planlaması sürecinin kıyı alanlarının sürdürülebilir şekilde yönetimi ve planlanması konusunda etkili bir sonuç sunmadığı görülmektedir. Kıyı alanlarında özellikle son yıllardaki hızlı ve plansız yapılaşma, doğal kaynakların zarar görmesi ve bütüncül bir yaklaşım ile bu alanlar için uzun vadeli vizyon ve stratejiler üretilememesi BKAY ve planlaması süreçlerinin yeniden ele alınması gerekliliğini ortaya koymaktadır.

Bu makalede, kapsamlı literatür taraması ve uzman görüşmeleri çerçevesinde BKAY ve planlaması süreçlerinin yetersizlikleri ve sınırlılıkları açısından stratejik mekansal planlama süreçleri ile benzerlikler gösterdiği saptanmıştır. Ayrıca, yapılan görüşmeler sonucunda BKAY süreci ile ilgili olarak da izlenmesi gereken yöntemler ve yapılması gereken eylemlere yönelik oydaşma sağlanan evrensel nitelikte ilke, esas, hedef, strateji oluşturulması yönünde de öneriler geliştirilmiştir. BKAY ve planlaması süreçlerinin başarıyla gerçekleştirilebilmesi için stratejik mekansal planlama süreçlerinin olumlu yönleri ile entegrasyon sağlanabilmeli ve bu süreçler eylem planları ile desteklenerek hedeflerin gerçekleşmesi yönünde adımlar atılabilmelidir.

Türkiye sahip olduğu kıyı alanlarının varlığı ve özellikleri bakımından önemli ülkeler arasında yer alması nedeniyle, BKAY ve planlanmasının etkin ve yeterli bir biçimde uygulanması gerekliliği ortaya çıkmaktadır. Öncelikle yatay ve dikey kurumsal ve yasal düzenlemeler ile stratejik mekansal planlarda olduğu gibi çok sektörlü ve çok ölçekli ilişkilerin eşgüdümünün sağlanması gerekmektedir. Merkezi ve yerel yönetimlerin farklı görevler üstlenmesi, aralarındaki iletişimin çeşitli komisyon ve organizasyonlar ile sağlanması, kurumlar ve aktörler arasında yaşanan yetki karmaşasının giderilmesi gerekmektedir. 1990’lı 
yıllarda bu yönde çalışmalar gerçekleşmiş iken son yıllarda bu çalışmaların azaldığı görülmektedir.

Ayrıca, planlama sürecine yönelik de değişiklikler gerekmektedir. BKAY ve planlama süreçleri sadece mekansal olarak değil, stratejik olarak da farklı ölçeklerde ve çeşitli tematik sektörel planlar ile birlikte tasarlanmalı, üst ölçekli bölgesel stratejiler içeren bir yaklaşımın mekansal planlama sistemine de entegre olması sağlanmalıdır. Böylece, alansal olarak ortaya çıkan parçalı yapı bütünleştirilebilecek, farklı alanlarda alınan farklı planlama kararlarının birbirleriyle uyumu da sağlanabilecektir. Dışsal finans kaynaklarının fazla olması, uzun vadeli planların yapılabilmesi ve esnek planlama süreçlerinin tanımlanabilmesi, sektörel planların da BKAY'ı desteklemesi ile kıyı alanlarında koruma dengesi sağlanabilmesi ve üretim odaklı süreçlerin daha geri planda tutulabilmesi ile gelişmekte olan bir ülke olarak Türkiye'de BKAY'ın başarı seviyesi de arttırılabilecektir.

Bu kurumsal düzenlemeler ve planlama süreçlerine dair problemler uygun yasal altyapı ile desteklenebilmelidir. Üst ölçekli planların alt ölçekli uygulama planlarıyla da desteklenmesi sağlanmalıdır. Yasaların yol gösterici özelliklerinin yanısıra hukuki yaptırımının ve bağlayıcılığının olması, ayrıca diğer mekansal ve sektörel planlar arasındaki hiyerarşide de yerinin olması sağlanmalıdır. Çalışma kapsamında belirlenen konu başlıkları arasında görece farklılıklar bulunsa da çıkan bu sonuçlar doğrultusunda, önemli eksikliklerin olduğu saptanmıştır. Özellikle kurumsal, yasal ve planlamaya yönelik birtakım gelişmeler olsa da, izleme ve değerlendirme ile katılım gibi konularda daha somut adımların atılması gerekmektedir. Ancak, Türkiye'de BKAY ve planlaması ile ilgili bu düzenlemelerin gelişim aşamasında olduğu göz önünde bulundurulduğunda, atılacak adımların önemi daha da artmaktadır. Öte yandan, araştırma sonuçları, BKAY ve planlaması konusunda yeterli düzeyde uzmanlaşma, bilgi ve farkındalık olmadığını da göstermiştir. Bu nedenle, Türkiye'de BKAY ve planlaması ile ilgili tüm konu başlıkları için yerine getirilmesi ve geliştirilmesi gereken önemli noktalar bulunmaktadır.

Bu çalışma ile kıyı alanlarının yönetimi ve planlanması konusunda, tüm ölçeklerde yaşanan kentsel politikaların eksiklerinin ortaya çıktığı görülmektedir. Yönetsel düzeyler arasında eşgüdümün sağlanamaması, planlar arasında uyumsuzlukların olması, planlama süreçlerinde etkin katılımın sağlanamaması, yasal düzenlemelerde eksikliklerin olması gibi sorunlar, aynı zamanda Türkiye'de stratejik planlama sürecinin uygulama aşamalarının da temel eksiklikleri olarak karşımıza çıkmaktadır. Yürütülen çalışmaların yalnızca mekansal planlama olarak değil, bir stratejik plan yönetim süreci olarak ele alınması gerekliliği ortaya çıkmaktadır. Böylece, farklı boyutların bir araya gelmesi ile yeterli ve uygulanabilir çalışmaların üretilmesi olanaklı görülmektedir.

\section{KAYNAKLAR}

Albrechts, L. (2001). From Traditional Land Use Planning to Strategic Spatial Planning: The Case of Flanders. Albrechts, L., Alden, J., DaRosa Pires, A. (Editörler). The Changing Institutional Landscape of Planning. Londra: Routledge, 83-108.

Albrechts, L., Balducci, A. (2013). “Practicing Strategic Planning: In Search of Critical Features to Explain the Strategic Character of Plans". disP-The Planning Review, 49(3), 16-27.

Bahar, Ö. (2007). Türkiye İçin Bütünleşik Kıyı Alanları Yönetimi ve Denizel Konumsal Veri Altyapısının Önemi, Karadeniz Teknik Üniversitesi, Trabzon, Yayınlanmamış Yüksek Lisans Tezi.

Carter, H.N., Schmidt, S.W., Hirons, A.C.(2015). "An International Assessment of Mangrove Management: Incorporation in Integrated Coastal Zone Management". Diversity, 7(2), 74-104.

Christie, P. (2005). “Is Integrated Coastal Management Sustainable?". Ocean and Coastal Management, 48(3-6 SPEC. ISS.), 208-232.

Commission of the European Communities (CEC). (2002). Recommendation of the European Parliament and of the Council of 30 May 2002 concerning the implementation of Integrated Coastal Zone Management in Europe. 2002/413/EC. Official Journal L.148:24.

Devlet Planlama Teşkilatı (1997). Ulusal Çevre Eylem Planı: Arazi Kullanımı ve Kıyı Alanlarının Yönetimi, Ankara, 3-65.

Devlet Planlama Teşkilatı (2006). IX. Kalkınma Planı Çevre Özel İhtisas Komisyonu Raporu (2007-2013), Ankara: Devlet Planlama Teşkilatı, 15-90.

Duru, B. (2003). Kıyı Politikası (Birinci baskı). Ankara: Mülkiyeliler Birliği Vakfi Tezler Dizisi:13, 13-326.

Eke, F. (1995). Kıyı Mevzuatının Gelişimi ve Planlanma (Dördüncü baskı). Ankara: Bayındırlık ve İskan Bakanlığı Teknik Araştırma ve Uygulama Genel Müdürlüğü, 5-50.

Enemark, J. (2005). "The Wadden Sea protection and management scheme - Towards an integrated coastal management approach?". Ocean and Coastal Management, 48(11-12), 996-1015.

Eraydın, A. (2008). Planlamadan Uygulamaya, 3. Bölgesel Kalkınma ve Yönetişim Sempozyumu Bildiri Kitabı, 27-28 Kasım, Mersin.

Friedmann, J. (2004). "Strategic Spatial Planning and The Longer Range". Planning Theory \& Practice, 5(1), 49-67.

Gedikli, B. (2004).Strategic Spatial Planning and Its Implementation in Turkey: Şanluurfa Provincial Development Planning Case, ODTÜ, Ankara, Yayınlanmamıș Doktora Tezi.

Görer, N., Duru, B. (2001). Türkiyéde Kıyı Yönetimi Uygulamaları. Türkiye Kıyı Alanları Yönetimi Milli Komitesi III. Ulusal Konferansı, Ankara.

Gülbitti, M. (2017). Türkiyédeki Bütünleșik Kıyı Alanları Yönetimi ve Planlamasının İncelenmesi, Gazi Üniversitesi, Fen Bilimleri Enstitüsü, Ankara, Yayınlanmamış Yüksek Lisans Tezi.

Healey, P. (1999).“"European Developments in Strategic Spatial Planning”. European Planning Studies, 7(3), 14-27.

Healey, P. (2013). “Comment on Albrechts and Balducci: Practicing Strategic Planning". disP-The Planning Review, 49(3), 48-50.

Kalkınma Bakanlığı (2013). X. Kalkınma Planı Mekansal Planlama Özel İhtisas Komisyonu Raporu (2014-2018). Ankara: Kalkınma Bakanlığı, 39-110.

Keleş, R. (2008). Kentleşme Politikası (Onuncu Baskı). İstanbul: İmge Kitabevi, 726-731.

Köroğlu, A. (2013). Turizm Merkezlerinde Bütünleşik Kıyı Alanları Yönetimi Antalya-Kaş Örneği, Uzmanlık Tezi, Kültür ve Turizm Bakanlı̆̆ı, Ankara, 19-56.

Kurt, S. (2015).“Türkiyéde Kıуı Kullanımına Yönelik Yasa ve Düzenlemelerin Tarihi Seyri”. Eastern Geographical Review, 20(33), 91-110. 
Mojica Vélez, J., Barrasa, S., Espinoza Tenorio, A. (2018).“Policies in Coastal Wetlands: Key Challenges". Environmental Science and Policy. 88.

Özelçi Eceral, T., Özdemir Sönmez, N. (2011). “Bütünleşik Kıyı Alanları Yönetimi ve Türkiyéde Kıyı-Planlama Mevzuatı ile Kurumsal Yapı", Yasal ve Yönetsel Boyutlarıyla Planlama, Prof. Dr. Feral Ekéye Armağan, Bayındırlık ve İskan Bakanlığı, TAU Genel Müdürlüğü Yayınları, Ankara, 118-135,ISBN:978-975-490-010-1

Özkalp, E. (2016). Sosyolojiye Giriș ve Yöntemi, Kırel, A.Ç., Sungur, Z. (Editörler). Davranış Bilimleri-1. Yedinci Baskı. Eskişehir: Anadolu Üniversitesi, 13-23.

Özügül, M.D., Yerliyurt, B., Seçilmişler, T. (2017). "Evaluation of Integrated Coastal Zone Management Plan Practices in the Turkish Case", IOP Conf. Series: Materials Science and Engineering 245062032 doi:10.1088/1757-899X/245/6/062032

Percoco, M. (2016). “Strategic Planning and Institutional Collective Action in Italian Cities". Public Management Review, 18(1), 139-158.

Post, J. C., Lundin, C.G. (1996). Guidelines for Integrated Coastal Zone Management, Environmentally Sustainable Development Studies and Monographs Series No.9, The WorldBank, Washington D.C.

Sınacı, F., Büyükgöçmen Sat, N.A. (2009). Stratejik Mekansal Planlamanın Yasal Boyut Açısından Değerlendirilmesi: Türkiye-AB Karşılaştırması, Gazi Üniversitesi, Fen Bilimleri Enstitüsü, Ankara, Yayınlanmamış Yüksek Lisans Tezi.

Sönmez, R., Balaban, O.(2009).” İskenderun Körfezi Kıyı Alanları Bütünsel Planlama ve Yönetim Projesi”. Planlama Dergisi, 1(29), 25-51.

Şimşek Deniz, S. (2014). Stratejik Mekansal Planlama ve Düzenleyici Geleneksel Planlamanın Katılım, Eylem Projeleri ve Esneklik Boyutlarinda İncelenmesi - Bursa İli Örneği, İTÜ Fen Bilimleri Enstitüsü, İstanbul, Yayınlanmamış Yüksek Lisans Tezi.

Uçlar, S. (2012). Bütünleşik Kıyı Alanları Yönetimi ve İstanbul Örneği, İTÜ, Fen Bilimleri Enstitüsü, İstanbul, Yayınlanmamış Yüksek Lisans Tezi.

UNEP/MAP (2012). Akdeniz Deniz ve Kıyı Çevresinin Durumu, Karar Vericiler İçin Özet. UNEP/MAP Raporu, 3. 